\title{
评述克拉通破坏与西太平洋板块俯冲专题
}

\section{郯庐断裂带晚中生代演化对西太平洋俯冲历史的 指示}

朱光", 刘程, 顾承串, 张帅, 李云剑, 苏楠, 肖世楖

合肥工业大学资源与环境工程学院, 合肥 230009

* E-mail: zhuguang59@hotmail.com

收稿日期：2017-06-27; 收修改稿日期：2017-11-02; 接受日期：2017-11-07; 网络版发表日期：2018-01-30

国家自然科学基金项目(批准号: 41472186、91414301)和国家重点研发计划项目(编号: 2016YFC0600102)资助

摘要 北东-北北东走向的郯庐断裂带是中国东部规模最大的断裂带, 为滨太平洋构造的典型代表. 该断裂带晚 中生代的演化过程是古太平洋(伊泽奈崎)板块俯冲作用的结果，也指示了后者的俯冲历史。继中三叠世起源之后， 㸚庐断裂带在中侏罗世末首次复活, 仅在大别造山带东缘可识别出这期左行平移历史, 应代表了古太平洋板块俯 冲作用的开始. 继晚侏罗世平静期后, 该断裂带在早白严世初发生了强烈的左行平移活动, 是近南北向挤压的结 果, 其动力学背景为伊泽奈崎板块向北北西向高速低角度俯冲. 在早白严世期间, 郯庐断裂带转变为强烈的伸展 活动，与华北克拉通东部峰期破坏同时发生，为伊泽奈崎俯冲板片后撤导致的弧后拉张结果。该断裂带在早白严 世末再次经历了压扭性的左行平移, 标志着华北克拉通峰期破坏的结束。在晚白严世期间, 郯庐断裂带呈现为弱 伸展活动, 处于远场弧后弱拉张的动力学背景下. 由此可见, 敞庐断裂带在晚中生代经历了压扭性平移与伸展活 动的多次交替. 在区域挤压背景下发生的左行平移活动时间相对短暂, 而伸展活动则持续时间相对较长, 与古太 平洋板块俯冲方式与历史有关.

关键词郯庐断裂带, 左行平移, 伸展活动, 伊泽奈崎板块, 太平洋板块

\section{1 引言}

大型断裂带是岩石圈内薄弱带，从而对区域构造 运动十分敏感, 是区域动力学演化历史的最佳记录者. 活动大陆边缘的大地构造演化，主要受控于大洋板块 的俯冲作用，由此可以反演大洋板块的作用方式与过 程. 活动大陆边缘上的大型断裂带, 特别是平行于海 沟俯冲带的大型断裂带, 同样也是大洋俯冲作用的理
想记录者, 是认识活动大陆边缘构造作用与大洋俯冲 作用耦合关系的重要窗口. 中国东部巨型的郯庐断裂 带就是这种认识西太平洋俯冲历史的关键对象.

北东-北北东走向的郯庐断裂带, 是中国东部规模 最大的断裂带, 走向上平行于西太平洋的板块俯冲带. 大量的研究表明(Okay和Şengör, 1992; Yin和Nie, 1993; Li, 1994; Lin和Li, 1995; Chung, 1999; Gilder等, 1999; Zhang等，2007; Zhu等，2009; Zhao等，2016；Li等，

中文引用格式: 朱光, 刘程, 顾承串, 张帅, 李云剑, 苏楠, 肖世梆. 2018. 㸚庐断裂带晚中生代演化对西太平洋俯冲历史的指示. 中国科学: 地球科学, 48: 415435, doi: 10.1360/N072017-00213

英文引用格式: Zhu G, Liu C, Gu C C, Zhang S, Li Y J, Su N, Xiao S Y. 2018. Oceanic plate subduction history in the western Pacific Ocean: Constraint from late Mesozoic evolution of the Tan-Lu Fault Zone. Science China Earth Sciences, 61: 386-405, https://doi.org/10.1007/s11430-017-9136-4 
2017), 该断裂带起源于中三叠世华北克拉通与华南陆 块的陆-陆碰撞造山过程中, 随后在西太平洋的板块俯 冲作用下多期活动. 郯庐断裂带晚中生代以来的多期 活动是西太平洋俯冲作用的响应已被多数学者所认同 (Xu等, 1987, 1993; Xu和Zhu, 1994; Zhang等, 2003; 朱 光等, 2004; Zhu等, 2005, 2010, 2012; Wang, 2006; Mercier等, 2007; 顾承串等, 2016; Gu等, 2017). 以往的 研究认为, 鄰庐断裂带在晚中生代的左行平移活动是 区域斜向挤压或压扭性剪切作用的结果, 对应于古太 平洋板块高速低角度俯冲作用 $(X u$ 等, 1987, 1993; 朱 光等, 2004; Zhu等, 2005, 2010; Wang, 2006; 顾承串等, 2016); 而其伸展活动则是大洋俯冲板片后撤所导致的 远场弧后拉张(Zhang等, 2003; Zhu等, 2012; Mercier等, 2007; Gu等, 2017). 众所周知, 华北克拉通东部在晚中 生代强烈伸展背景下发生了岩石圈减薄与克拉通破 坏, 其动力学背景为古太平洋俯冲板片后撤(朱日祥 等, 2012). 因而, 深入理解晚中生代期间华北克拉通 东部与古太平洋板块之间的动力学联系, 对于认识克 拉通破坏及大陆边缘演化具有十分重要的意义.

近年来对于㸚庐断裂带的深入研究成果, 为揭示 晚中生代古太平洋板块动力学作用的详细过程提供了 重要的信息. 本文重点总结华北克拉通东部郯庐断裂 晚中生代学构造特征与演化历史, 综述近年来的研究 进展. 在此基础上, 尝试应用该断裂带的演化过程反 演古太平洋板块晚中生代期间的详细作用过程, 以此 揭示华北克拉通晚中生代破坏的动力学过程.

\section{2 类庐断裂带概况}

㸚庐断裂带南起长江北岸的湖北武穴, 经安徽庐 江、山东郯城、渤海, 过沈阳后分为西支的依兰-伊通 断裂带和东支的敦化-密山断裂带(也称为密山-抚顺断 裂带), 总体呈北北东走向, 在中国境内长达 $2400 \mathrm{~km}$ (图 1). 该断裂带自南向北分别经过华南陆块、大别-苏鲁 造山带、华北克拉通与中亚造山带东部的兴蒙造山 带. 在华北克拉通东部, 郯庐断裂带纵贯南北, 以一个 巨型构造带形式存在, 也是该区中生代以来活动性最 强、活动期次最多的构造带.

在中三叠世华北克拉通与华南陆块碰撞造山中, 㸚庐断裂带以左行走滑断裂带形式出现, 目前地表出 露的这期构造呈现为走滑韧性剪切带(Zhang等, 2007;
Zhu等, 2009; Zhao等, 2016). 由于其起源于碰撞造山之 中, 当时形成的断裂带仅出现于大别与苏鲁造山带之 间，向北并没有延入现今的渤海地区(Zhu等，2009; Zhao等, 2016). 显然, 该断裂带起源于古特提斯构造, 在随后的滨太平洋构造域复活, 从而转变为受控于大 洋板块俯冲作用的滨太平洋构造(Xu等, 1987, 1993; Zhu等, 2005, 2010, 2012).

在晚中生代期间, 淡庐断裂带的走滑与伸展活动 交替发生(Zhu等, 2005, 2010, 2012), 记录了活动大陆 边缘详细的构造过程. 进入新生代, 该断裂带仍然多期 而强烈地活动. 在古近纪期间, 该断裂带呈现为强烈的 伸展活动, 一方面沿断裂带出现玄武岩喷发, 另一方面 在华北克拉通东部自南向北分别控制发育了合肥盆地 与渤海湾盆地东部(Ren等, 2002; Zhu等, 2012). 在新近 纪期间, 缸庐断裂带主要呈现为弱伸展活动(詹润等, 2013), 沿断裂带继续出现玄武岩喷发(牛漫兰等, 2005). 第四纪期间, 该断裂带受到近东西向的挤压, 呈现为右行逆平移活动, 并成为华北克拉通东部最强 的地震活动带(Liu等, 2015; Zhu等, 2015a).

郯庐断裂带经历过多阶段、不同性质的演化历 史, 所形成的不同类型断裂构造相互叠加与交织. 该断 裂带中生代期间形成的走滑构造, 目前以韧性剪切带 形式局部保存在变质岩内. 断裂带内新生代期间发育 的各类构造皆为脆性构造, 包括脆性的正断层、逆断 层与平移断层, 复合的影响宽度最大可达 $40 \mathrm{~km}$. 该断 裂带晚中生代以来多期的伸展活动, 除了出现多期的 正断层外, 还控制发育了一系列伸展盆地. 在华北克 拉通东部, 该断裂带的安徽部分控制发育了西侧的合 肥盆地, 其江苏-山东部分控制发育了沂沭裂谷与东侧 的胶莱盆地, 而在渤海海域控制发育了渤海湾盆地东 部. 在郯庐断裂带伸展活动期间, 还诱发了一系列的 岩浆活动, 包括早白垩世的中-酸性岩浆活动与新生代 的玄武岩喷发. 这些岩浆活动及其地球物探测表明(朱 光等, 2002; 牛漫兰等, 2002, 2005; Chen等, 2006), 郯庐 断裂带目前已穿岩石圈, 成为切割深、延伸长的岩石 圈断裂带.

\section{3 断裂带晚中生代演化历史}

长期以来，郯庐断裂带以其中生代左行平移活动 为特色, 被当作中国东部大型平移断裂的典型代表 


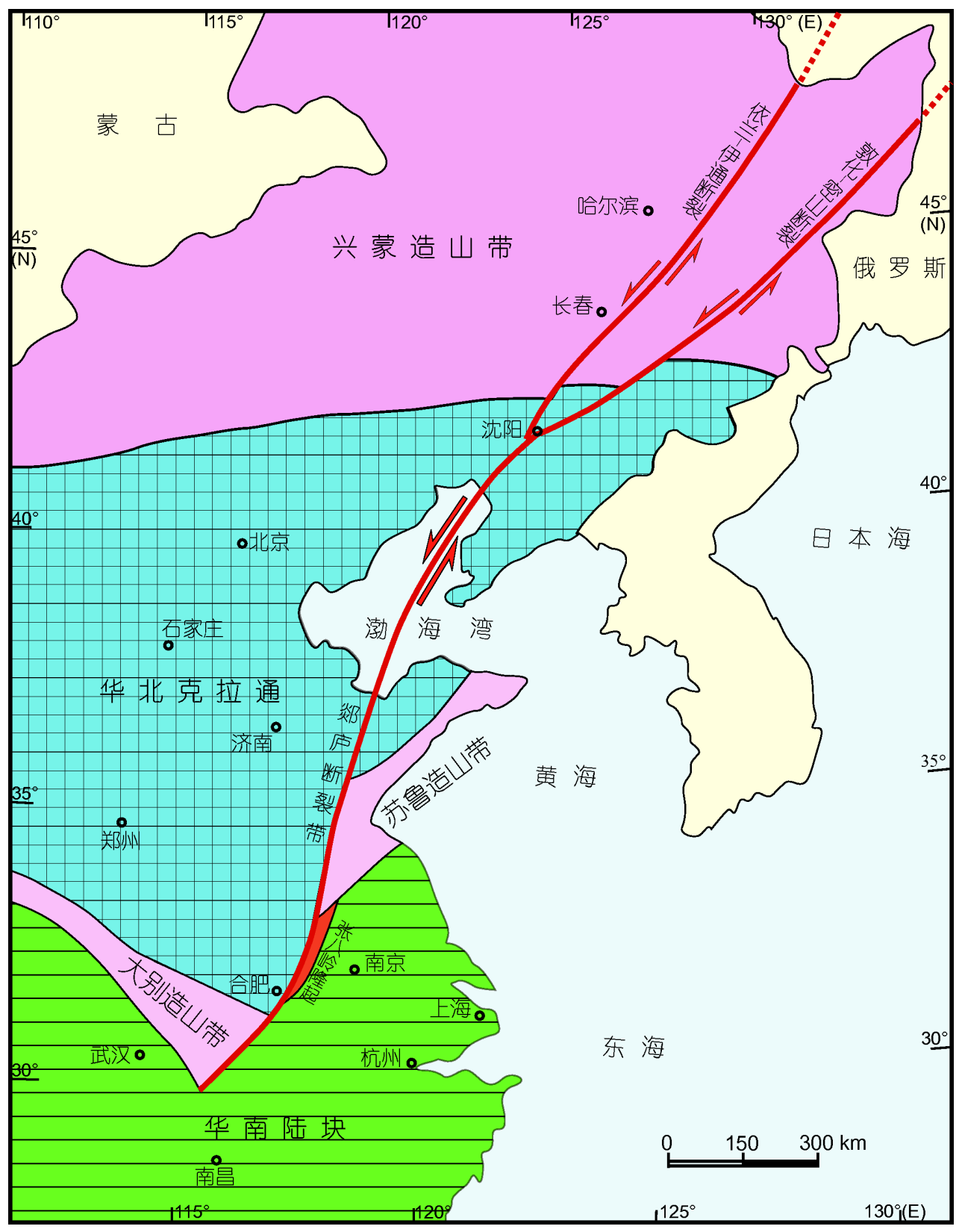

图 1 検庐断裂带构造简图

据朱光等(2004)修改

(Xu等, 1987, 1993). 近年来的详细研究表明, 该断裂在 晚中生代呈现为走滑与伸展活动交替发生，具有多期 而复杂的演化历史.

\section{1 中侏罗世末左行平移活动}

一系列构造与年代学研究表明 $(X u$ 等, 1987, 1993; Zhu等, 2005, 2010; Wang, 2006), 继中三叠世起源之后,
淡庐断裂带的首次复活呈现为左行平移，产生了走滑 韧性剪切带. 在大别造山带东缘, 㸚庐左行走滑韧性 剪切带出现在造山带变质岩内(图2). 该段剪切带产状 陡立, 矿物拉伸线理平缓, 露头及显微构造均指示为左 行剪切(Zhu等, 2005, 2010). 该处郯庐走滑剪切带还明 显牵引、弯曲超高压变质带与晓天-磨子潭断裂(图2), 也明显指示造山带折返后发生过郯庐断裂带的左行平 


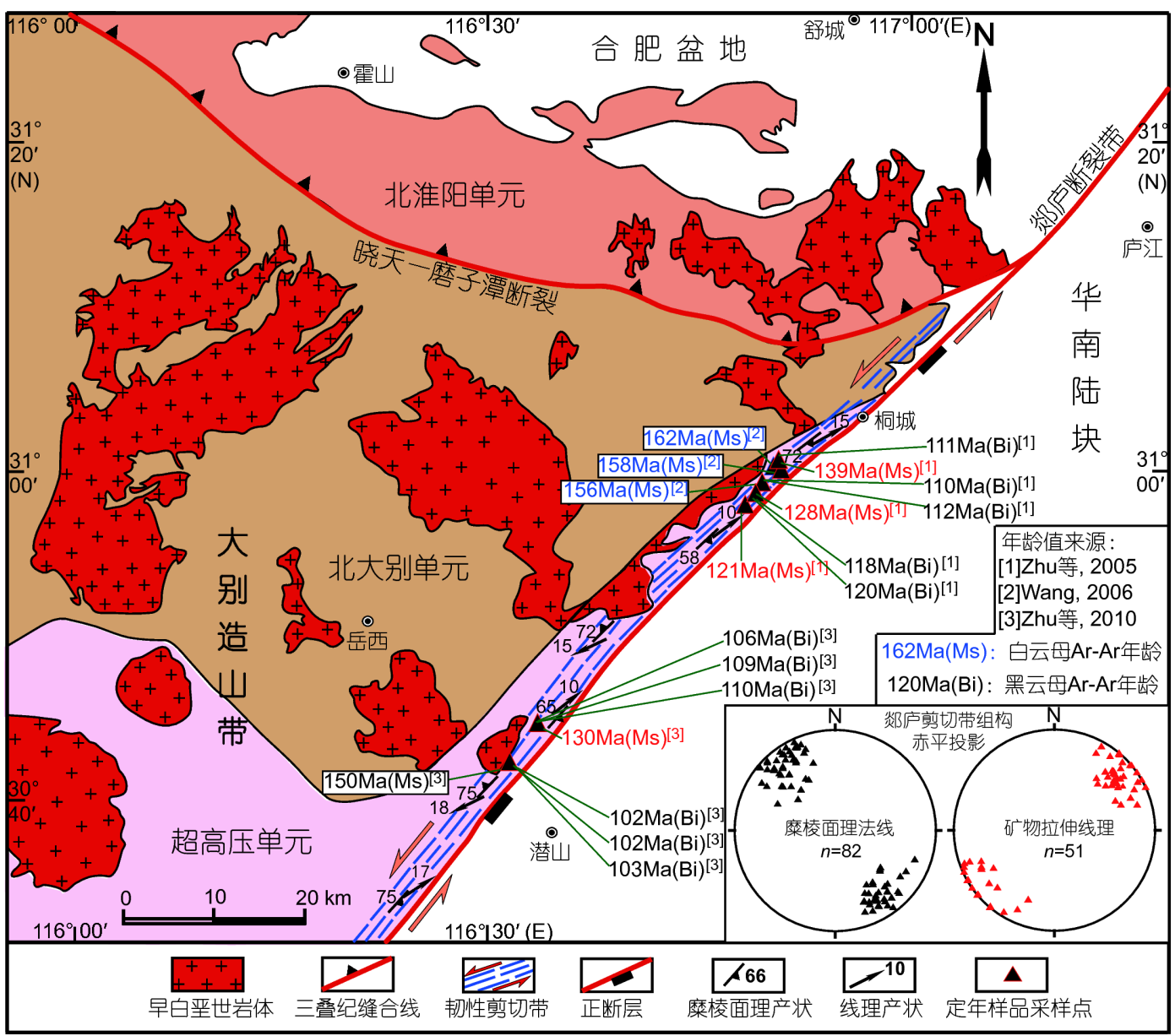

图 2 大别造山带东缘泟庐㓞性剪切带构造图与定年结果

据Zhu等(2005)修改

移活动. Wang(2006)和Zhu等(2010)通过对该段走滑韧 性剪切带内白云母的 ${ }^{40} \mathrm{Ar} /{ }^{39} \mathrm{Ar}$ 定年, 获得了162 150Ma 年龄值(图2). 一般 ${ }^{40} \mathrm{Ar}{ }^{39} \mathrm{Ar}$ 同位素年龄的最大值最接 近变形年龄，这些定年结果应指示郯庐断裂带在中侏 罗世末发生过一期左行平移活动. 值得指出的是，大 别造山带内部已有的大量年代学研究，并没有显示这 一期的同位素年龄值，也没有这一期岩浆活动，指示 造山带内部这期间没有发生过明显的构造-热事件. 因 而，大别造山带东缘㸚庐剪切带内162 150Ma年龄值， 应代表了一期该断裂带本身的左行平移活动. 然而, 郯 庐断裂带中-南段其他部位目前仍没有发现这期左行 平移活动的记录，指示这期左行平移活动可能仅在断 裂带南部(大别造山带东缘)局部出现.

多年来的研究表明，郯庐断裂带继中侏罗世末发 生过局部的左行平移活动之后，随后的晚侏罗世期间
没有明显的活动迹象，处于构造活动的平静期. 这期 间的断裂带沿线没有盆地发育及相应的沉积记录，指 示为整体隆起状态. 该断裂带内部至今也没有发现晚 侏罗世岩浆活动的记录.

\section{2 早白严世初左行平移活动}

淡庐断裂带在早白严世初再次发生了左行平移活 动已被一系列研究所证实 $(\mathrm{Xu}$ 等，1993; Xu和Zhu, 1994; Zhu等, 2005, 2010; Mercier等, 2007; 张岳桥和 董树文，2008). 这期走滑构造在渤海湾以南的中、南 段被广泛发现．在大别造山带东缘(图2)，㸚庐左行走 滑㓞性剪切带糜棱岩给出的另一组白云母 ${ }^{40} \mathrm{Ar}{ }^{39} \mathrm{Ar}$ 年 龄为 $139 \sim 121 \mathrm{Ma}(\mathrm{Zhu}$ 等，2005，2010), 其最大值 (139Ma)应接近该期左行平移时间(Zhu等, 2005), 而其 他较小值应为不均匀的冷却时间. 该段走滑韧性剪切 
带糜棱岩还给出了更年轻的、120 102Ma的黑云 $母^{40} \mathrm{Ar} /{ }^{39} \mathrm{Ar}$ 年龄值(Zhu等, 2005,2010 ; 图2), 皆属于冷 却年龄, 并与大别造山带伸展隆升及强烈岩浆活动时 间相吻合(Wang Y S 等, 2011), 也与矨庐断裂带的伸 展活动、盆地发育及上盘(造山带一侧)抬升时间相吻 合, 因而不能代表走滑活动时间. 该段剪切带部分被不 变形的早白严世岩体(小于139Ma，Zhu等，2010；图2) 所侵入，显示左行韧性剪切活动发生在早白严世早期 岩浆活动之前.

郯庐断裂带张八岭隆起段位于大别与苏鲁造山带 之间的华南陆块西缘(图1)，其西侧为华北克拉通上的 合肥盆地. 张八岭隆起南段出露低角闪岩相变质的新 元古代肥东杂岩(石永红等, 2009; 赵田等, 2014), 其中 发育了北东走向的㸚庐走滑韧性剪切带(图3). 该段郯 庐㓞性剪切带最大出露宽度可达约 $10 \mathrm{~km}$, 为多条剪切 带构成的复合型剪切带. 其北部因出露层次较深而呈 现为透入性的韧性走滑组构, 而出露层次相对较浅的 南部在走滑剪切带之间仍保留有早期韧性组构(图3). 这些㓞性剪切带主体向南东陡倾，其中的矿物拉伸线 理多向南西缓倾(图3). 露头与显微构造均指示这些剪 切带为左行走滑运动, 并具有一定的逆冲分量 $(\mathrm{Zhu}$ 等, $2005)$. 其中糜棱岩内角闪石给出了 $143 \mathrm{Ma}$ 的 ${ }^{40} \mathrm{Ar} /{ }^{39} \mathrm{Ar}$ 年龄, 而黑云母给出了 $137 \sim 119 \mathrm{Ma}$ 的 ${ }^{40} \mathrm{Ar} /{ }^{39} \mathrm{Ar}$ 年龄值 (Zhu等, 2005; 图3). 这些定年结果表明, 该段郯庐断 裂带的左行平移活动发生在约 $143 \mathrm{Ma}$ 的早白严世初 (Zhu等, 2005). 而较年轻的黑云母年龄(137 119Ma) 应 为冷却年龄, 可能分别记录了走滑隆升及随后伸展与 岩浆活动导致的隆升时间. 由此可见，郯庐断裂带张 八岭隆起南段记录了早白严世初的左行平移活动.

㸚庐断裂带山东段也称为沂沭断裂带，介于华北 克拉通与苏鲁造山带之间(图1). 该段断裂带在白严纪 的伸展活动中控制发育了两个地堑与其间的地垒. 该 地垒上出露的变质基底内, 发育有北北东走向的郯庐 走滑㓞性剪切带(Zhu等, 2010). 韧性剪切带向南东陡 倾, 矿物拉伸线理近水平, 各类剪切指向构造均指示为 左行剪切. 该剪切带糜棱岩内角闪石给出了 $132 \mathrm{Ma}$ 的 ${ }^{40} \mathrm{Ar} /{ }^{39} \mathrm{Ar}$ 冷却年龄(Zhu等, 2009), 也指示在早白严世 初发生过左行平移活动.

近年来研究表明(顾承串等, 2016), 矨庐断裂带北 段的依兰-伊通断裂带和敦化-密山断裂带也在早白严 世初发生了左行平移活动，代表了这两条大型断裂带
的起源. 正是这期强烈的左行平移活动, 使得郯庐断 裂带中、南段向北延伸而扩展进入东北地区 $(\mathrm{Xu}$ 等, 1987, 1993; 顾承串等, 2016). 在郯庐断裂南端, 这期左 行平移推挤西侧大别造山带向南运动, 但这一运动转 变为沿造山带南界上襄栎-广济断裂带的向南逆冲(李 三忠等, 2009; 王浩乾等, 2012), 从而使得该断裂带并 进一步向南扩展，仍然继承着印支期的总体构造格局 (Zhao等, 2016). 中国东部这期间还在郯庐断裂带旁侧 出现了一系列NE-NNE走向的左行平移断裂 $(X u$ 等, 1987, 1993; Xu和Zhu, 1994), 整体呈现为压扭性活动. 这一系列现象表明, 㸚庐断裂带在早白严世初的左行 平移活动是其晚中生代最强的一期平移活动, 整条断 裂带皆卷入了这期强烈活动, 并且还向北扩展进入东 北地区.

\section{3 早白严世期间伸展活动}

继早白严世初左行平移活动之后, 㸚庐断裂带在 早白严世中-晚期普遍转变为伸展活动, 呈现为巨型的 正断层带(Zhu等, 2010, 2012). 该断裂带在这期间的伸 展活动, 一方面控制发育了一系列裂谷盆地, 另一方面 诱发了强烈的岩浆活动. 在华北克拉通上, 沿断裂自南 向北分别发育了合肥盆地、嘉山盆地、沂沭地堑、胶 莱盆地、渤中盆地与辽河盆地(图4). 除合肥盆地与胶 莱盆地为半地堑式盆地外, 其他断裂带内部发育的盆 地主要为地堑式. 特别是该断裂带山东段在早白严世 期间发育了 4 条平行的大型正断层, 控制发育了沂沭 地堑(包括安丘-莒县与马站-苏村地堑及其间的录丹山 地; 图5; Zhu等, 2012).

郯庐断裂带在早白严世期间的伸展活动可以划分 为两个阶段 (Zhu等, 2012), 分别为强烈活动的早阶段 (135 115Ma，早白严世早-中期)和活动性减弱的晚阶 段(115 100Ma, 早白严世晚期). 早阶段对应盆地内地 层为山东的莱阳群/蒙阴组与青山组与安徽的朱巷组/ 周公山组/凤凰台组与毛坦厂组; 而晚阶段对应山东的 大盛群与安徽的响导铺组 (王薇等, 2017). 利用断层擦 痕反演应力场显示(Zhu等, 2012), 早白严世早-中期的 区域应力状态为WNW-ESE向拉张(图4), 有利于先存 的北东-北北东走向郯庐断裂带的复活与强烈正断层 活动. 这期间淡庐断裂带内部与旁侧皆是北东-北北东 走向正断层活动性最强(Zhu等, 2012), 相应的沉降带 也主要呈北东-北北东向展布(图4)。早白严世早-中期 


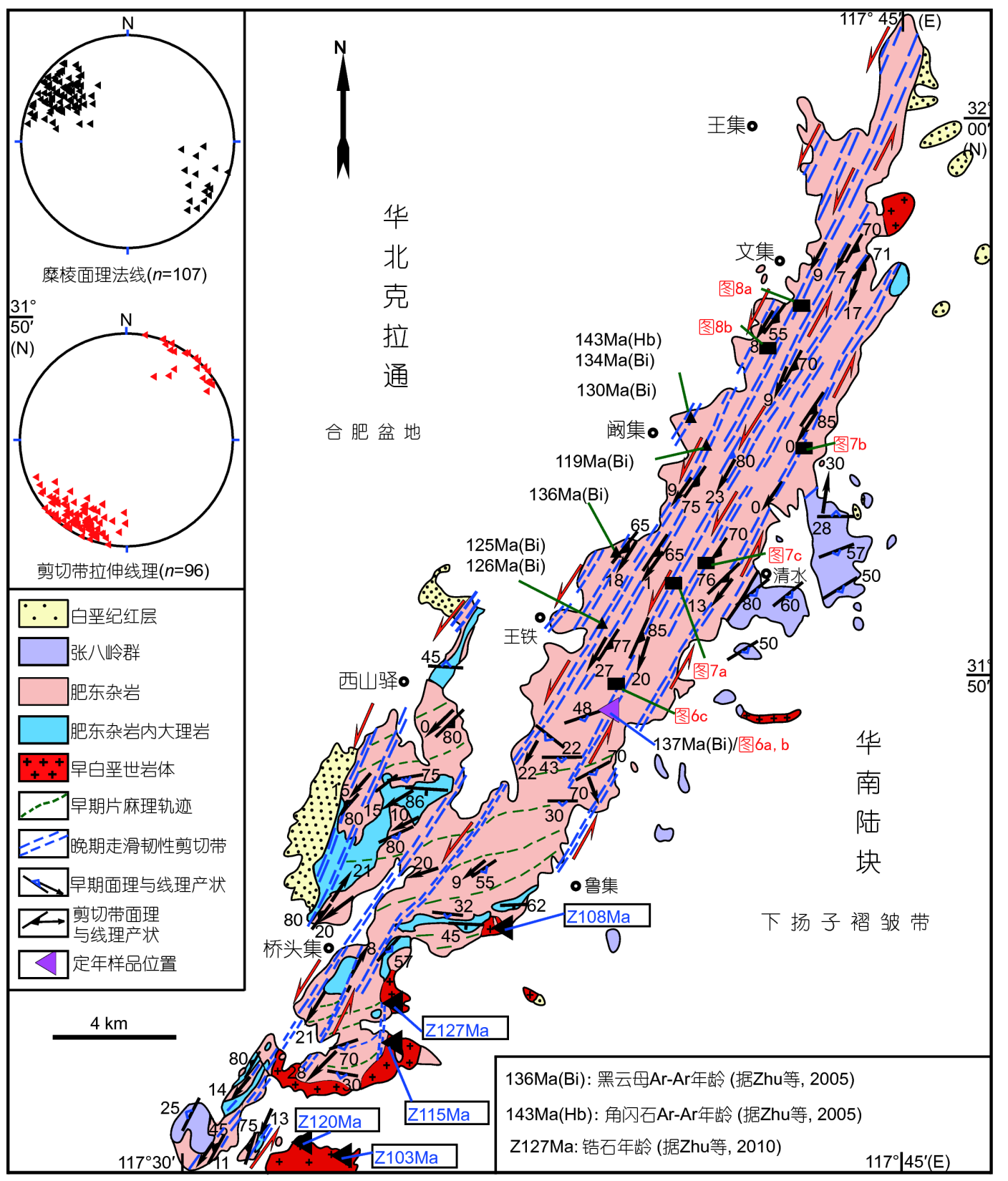

图 3 搂庐断裂带张八岭隆起南段平移构造图

据Zhu等(2005)修改

淡庐断裂带强烈伸展活动的另一个表现是成为强烈的 岩浆活动带. 在该断裂带所控制的断陷盆地内, 普遍出 现了中-酸性火山岩(山东的青山组与安徽的毛坦厂 组), 而在盆地外侧的隆起带上则发育了一系列中-酸 性侵入岩(图4)。一系列锆石微区U-Pb定年表明(Zhu 等, 2010, 2017; 王薇等, 2017), 这期间岩浆活动的开 始时间为 $135 \mathrm{Ma}$, 持续至 $115 \mathrm{Ma}$.
进入早白严世晚期，淡庐断裂带的伸展活动开始 减弱，控制发育的盆地范围缩小，岩浆活动也仅在南 部局部发育(图5). 这期间合肥盆地萎缩至东北部残存, 胶莱盆地没有接受沉积, 沂沭地堑则继续发育, 总体上 具有窄裂谷特征(Zhu等, 2012). 在岩浆活动方面, 也仅 在张八岭隆起南段零星发育酸性侵入岩(图5), 锆石U$\mathrm{Pb}$ 同位素年龄为 $108 \sim 102 \mathrm{Ma}(\mathrm{Zhu}$ 等，2010). 利用断层 


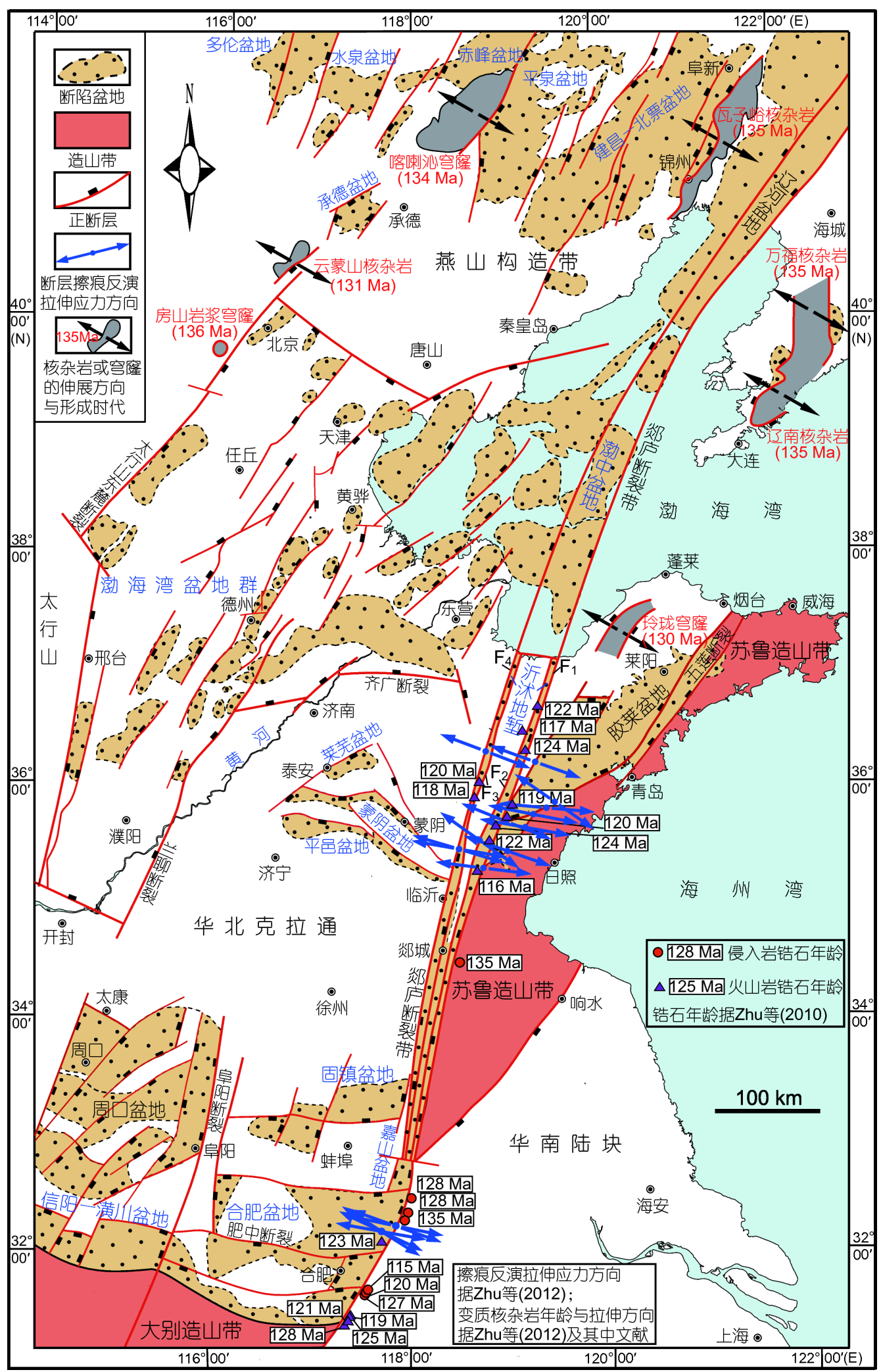

图 4 早白严世早-中期矨庐断裂带及其周边伸展构造图

据Zhu等(2012)修改 


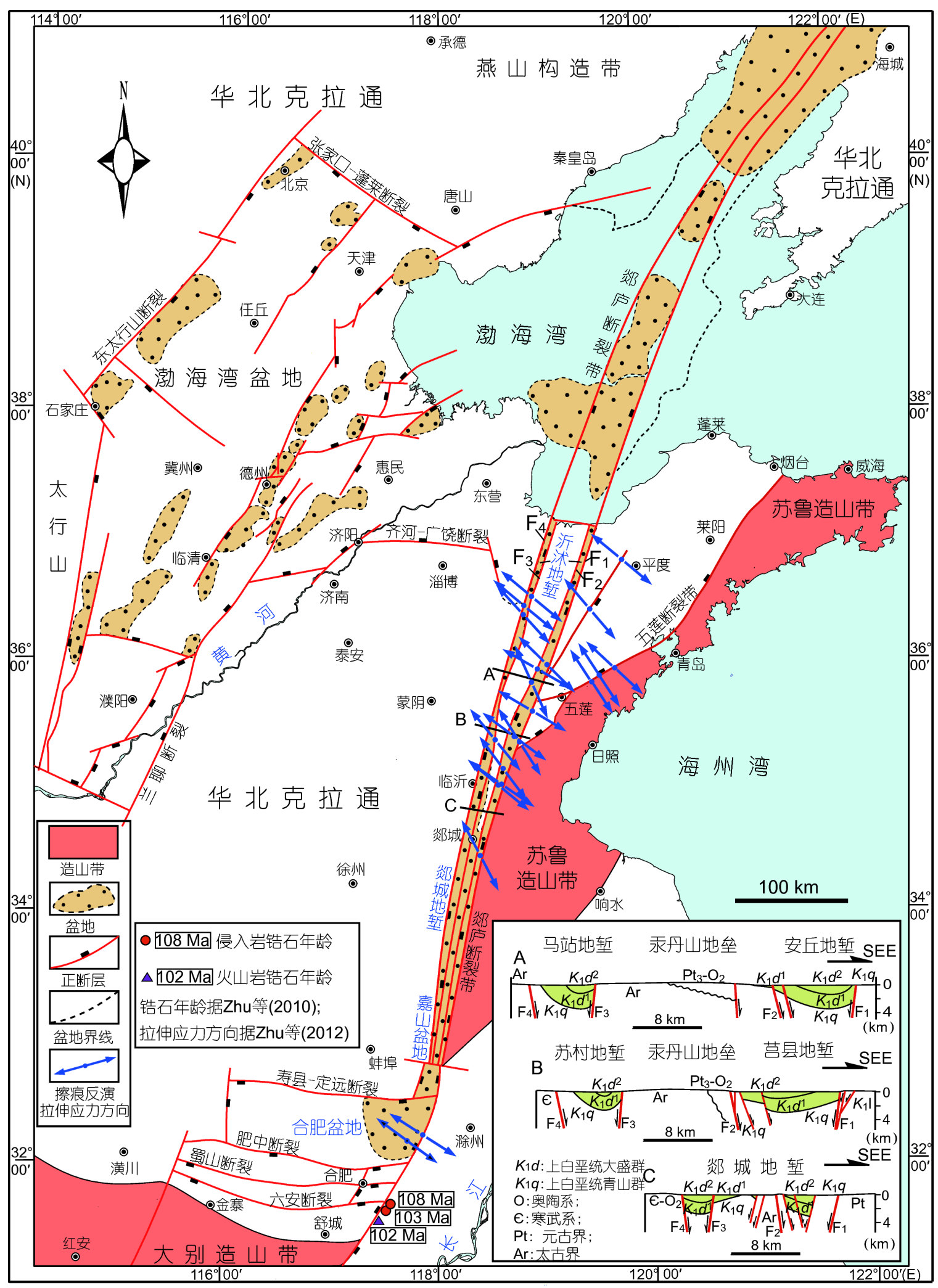

图 5 早白严世晚期矨庐断裂带及其周边伸展构造图

据Zhu等(2012)修改 
擦痕反演应力场显示(Zhu等，2012)，早白严世晚期的 应力状态呈现出了小幅度调整，转变为NW-SE向拉张 (图5).

\section{4 早白严世末左行平移活动}

郯庐断裂带张八岭隆起南段, 因露头良好而长期 成为详细研究走滑构造的对象. 如前文所述，该段在 早白严世初发育了北东走向的郯庐左行走滑韧性剪切 带(图3). 在早白严世伸展活动期间, 张八岭隆起南段 西缘发育西倾的正断层而控制发育了西侧合肥盆地 (图4)，而隆起带本身成为该正断层上升盘，内部侵入 了一系列中-酸性岩体(135 102Ma, Zhu等, 2010).

野外观察表明，早白严世初所形成的郯庐走滑韧 性剪切带, 皆没有切入这些伸展期侵位的岩体之中(图 2), 指示这期走滑剪切只是短暂活动. 在这期走滑韧性 剪切带内，还可见侵入其中的早白严世岩脉也没有卷 入剪切带韧性变形(图6). 在巢湖西韦采场东端, 发育 于肥东杂岩内的郯庐左行走滑㓞性剪切带, 其黑云 ${ }^{40} \mathrm{Ar}{ }^{39} \mathrm{Ar}$ 坪年龄为 $137 \mathrm{Ma}$ (图6a; Zhu等, 2005), 而侵 位于其中未变形花岗岩脉锆石 $\mathrm{U}-\mathrm{Pb}$ 年龄为 $122 \mathrm{Ma}(\mathrm{Zhu}$ 等, 2010). 在该采场中部, 同样也能见到侵入该期剪切 带内的未变形花岗岩脉(图6b). 通过在合肥工业大学 测试中心进行的锆石LA-ICP-MS U-Pb定年(网络版附 表1, http://earthen.scichina.com), 指示其侵入时代为 $126 \mathrm{Ma}$ (图6b). 在肥东王铁东桴槎山铁路采石场, 也可 见早白严世初形成的走滑剪切带内，侵入有末变形正 长岩脉(图6c), 锆石LA-ICP-MS U-Pb定年指示其侵位 时代为 $125 \mathrm{Ma}$ (网络版附表1). 这一系列现象表明, 郯庐 断裂带早白严世初的平移活动较为短暂, 在随后的早 白严世期间转变为伸展活动.

近年来的详细研究发现(王微等, 2015; 韩雨等, 2015), 张八岭隆起南段在早白严初左行走滑与早白严 世期间伸展与岩浆活动之后又叠加了一期左行走滑活 动. 野外可见该段两期北东走向左行走滑韧性剪切带 的叠加现象(图7). 在巢湖桃花源处(图7a), 早白严世初 形成的北东走向㸚庐左行走滑韧性剪切带(第一期, 肥 东杂岩内), 被 $131 \mathrm{Ma}$ 的花岗岩脉(韩雨等，2015)所侵 位. 这期岩脉侵位之后，该处再次叠加了左行走滑活 动，使得第二期剪切带内岩脉被剪切变形，而第二期 剪切带外岩脉却没有卷入变形. 另外, 王微等(2015)还 在该处变形岩脉内分别获得了 133 和 $129 \mathrm{Ma}$ 的锆石 U-
$\mathrm{Pb}$ 年龄, 指示该处第二期剪切带形成于 $129 \mathrm{Ma}$ 之后. 在 巢湖烟头山水库东铁矿采场(图7b), 第一期郯庐走滑 㓞性剪切带发育于 $165 \mathrm{Ma}$ 的花岗岩脉内(网络版附表 1), 并在第二期剪切带发育过程中被褶皱; 而其旁侧 $127 \mathrm{Ma}$ 的闪长岩脉(网络版附表1)仅卷入第二期左行走 滑韧性剪切带变形, 其中的面理没有发生褶皱. 在巢湖 寨山采场，也存在着两期郯庐左行走滑韧性剪切带(图 $7 \mathrm{c})$. 该处晚期北东向左行走滑㓞性剪切带明显切割早 期剪切带, 并使后者的糜棱面理发生了剪切褶皱(a型 褶皱)。该处 $124 \mathrm{Ma}$ 的花岗岩脉被晚期剪切带变形成糜 棱岩, 但其中的面理并没有发生褶皱.

随着研究的不断深入，早白严世侵入岩内发育晚 期走滑韧性剪切带现象在张八岭隆起南段更多处被确 认(图8). 在皖肥东解集梁巷东南(图8a), 可见北东走 向、向南东倾的左行走滑韧性剪切带发育于早白严世 花岗岩脉内, 锆石LA-ICP-MS U-Pb定年结果指示岩脉 的侵位年龄为 $128 \mathrm{Ma}$ (网络版附表1). 在皖肥东解集大 邵东南采场(图8b)，也可见同方位、同性质的走滑韧 性剪切带发育于早白严世花岗岩脉与闪长岩脉内, 锆 石 $\mathrm{U}-\mathrm{Pb}$ 定年结果指示它们的侵位年龄分别 132 和 $134 \mathrm{Ma}$ (网络版附表1). 这些现象进一步证实了郯庐断 裂带在早白严世岩浆活动之后又发生过一期左行平移 活动.

综上所述，郯庐断裂带张八岭隆起南段晚期左行 走滑活动，形成了相间出现的北东走向韧性剪切带, 但没有产生透入性的韧性变形. 因而，既可以见到早 白严世侵入岩在早期(早白严初)剪切带内未变形现象 (图6), 又可以见到早白严世岩脉在晚期剪切带被变形 成糜棱岩(图7和8). 卷入晚期走滑韧性剪切带的变形 岩脉，其侵位时间为134 124Ma，由此可以限定晚期 左行走滑活动发生在 $124 \mathrm{Ma}$ 之后. 如前文所述, 张八岭 隆起南段早白严世伸展期岩浆活动持续至 $103 \mathrm{Ma}$ (图3; Zhu等，2010)，指示郯庐晚期左行平移发生在早白严 世末.

一系列地质现象显示，㸚庐断裂带在早白严世末 (或晚白严世初)经历了一次重要的地质事件. 该断裂 带所控制的早白严世断陷盆地在早白严世末(或晚白 严世初)普遍经历了一次抬升、反转与沉积间断(Zhu 等, 2012). 地震剖面显示, 合肥盆地内下白严统响导铺 组与上白严统张桥组之间存在着角度不整合(刘伟等, 2004)，指示早白严世末(或晚白严世初)发生过一期挤 


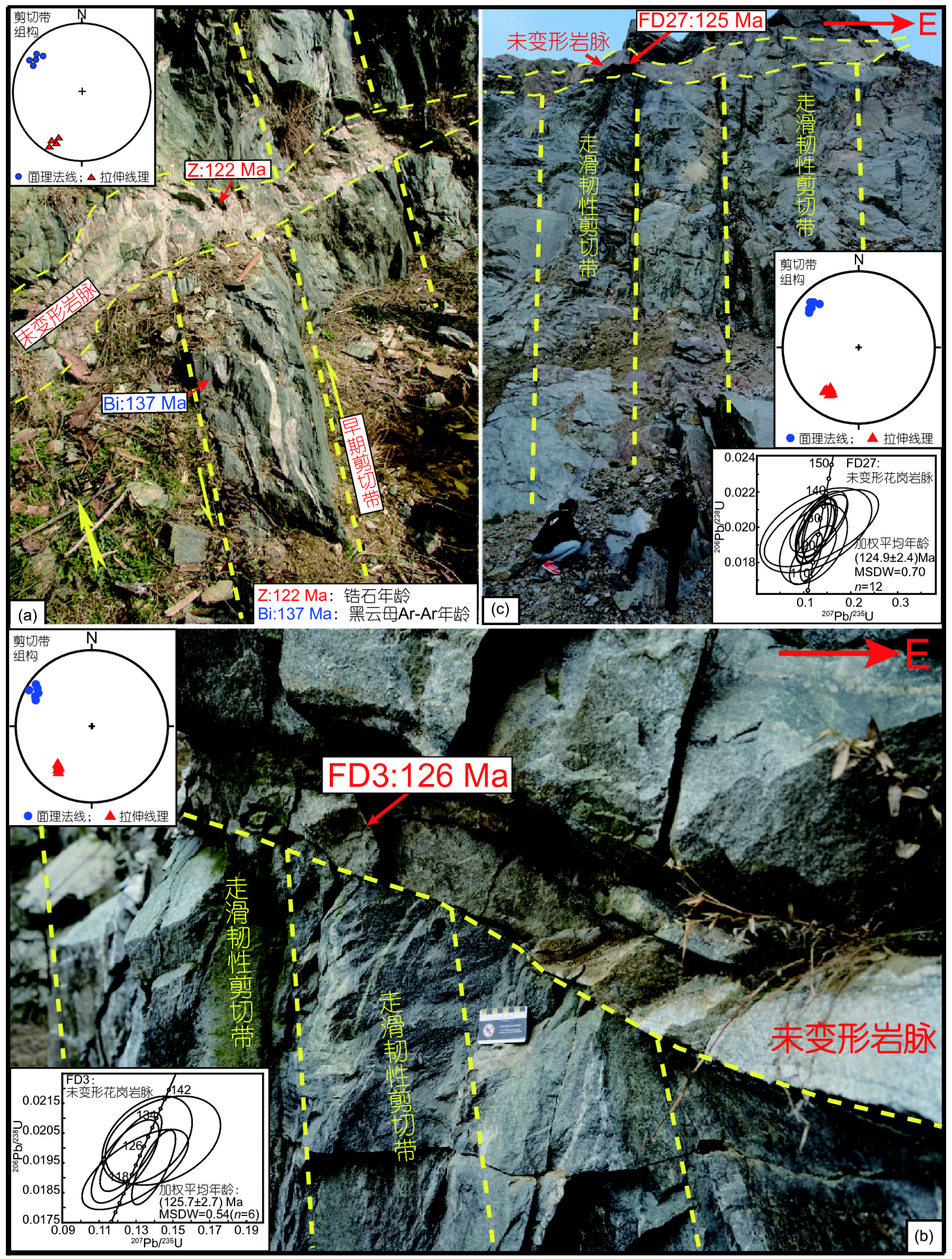

图 6 楼庐断裂带张八岭性起南段早白严世初走滑韧性剪切带、变形组构赤平投影、未变形岩脉及其锆石U-Pb谐和图 (a) 巢湖西韦, 剪切带黑云母 ${ }^{40} \mathrm{Ar}{ }^{39} \mathrm{Ar}$ 坪年龄据Zhu等(2005), 未变形岩脉锆石年龄据Zhu等(2010); (b) 巢湖西韦, 以及本次获得的未变形岩脉铅 石U-Pb谐和图; (c) 肥东王铁东桴槎山铁路采石场, 以及本次获得的未变形岩脉锆石U-Pb谐和图, 位置见图3 


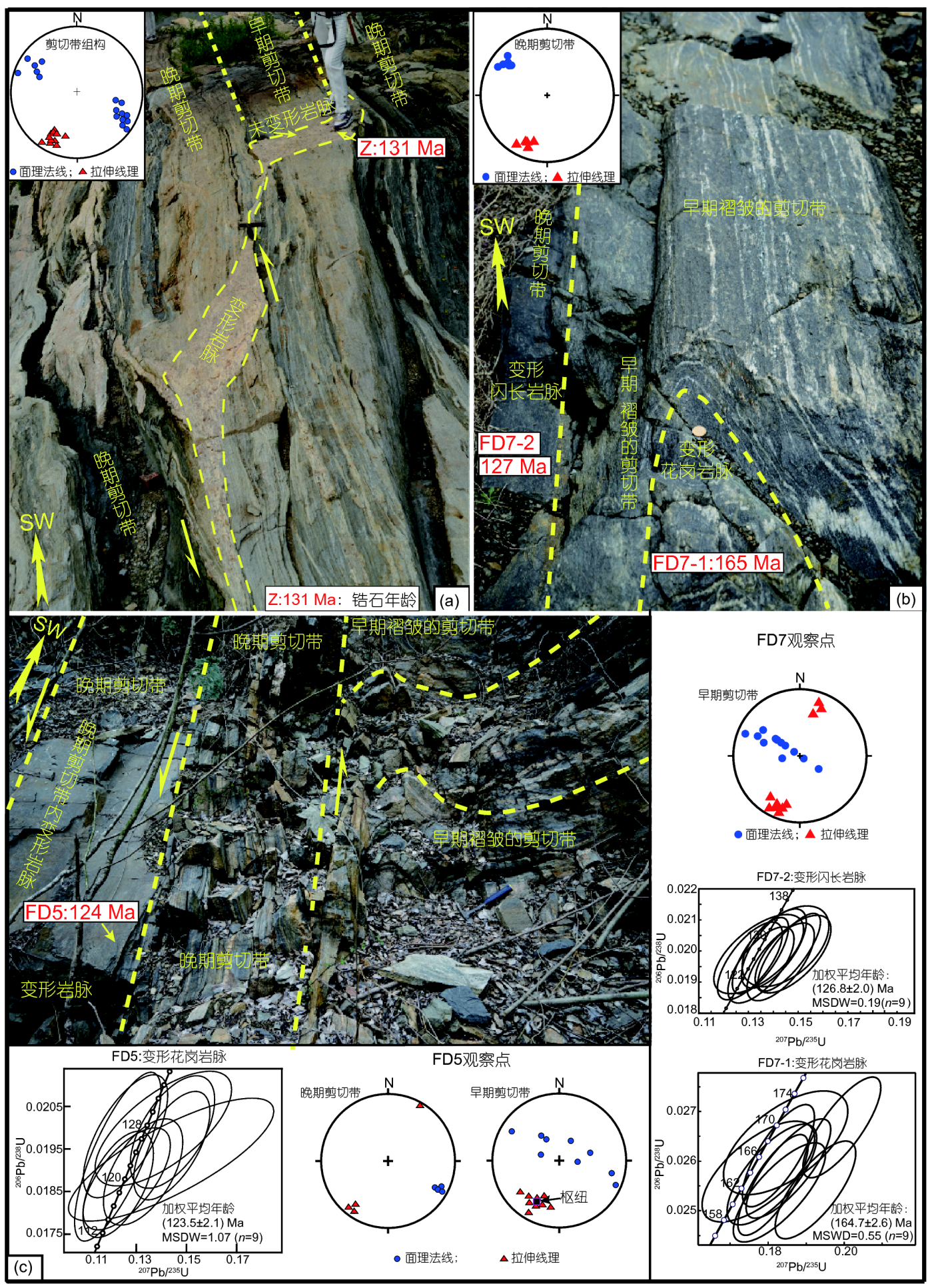

图 7 矨庐断裂带张八岭隆起南段两期左行走滑㓞性剪切带野外照片、变形组构赤平投影及锆石U-Pb定年结果

(a) 巢湖桃花园肥东杂岩内两期走滑韧性剪切带与早白严世岩脉部分卷入晚期剪切带, 岩脉铅石年龄据韩雨等(2015); (b) 巢湖烟头山水库东 铁矿采场中生代岩脉内两期走滑韧性剪切带及铅石U-Pb年龄谐和图; (c) 巢湖寨山采场两期走滑㓞性剪切带及晚期变形花岗岩脉铅石U-Pb年 龄谐和图, 位置见图3 


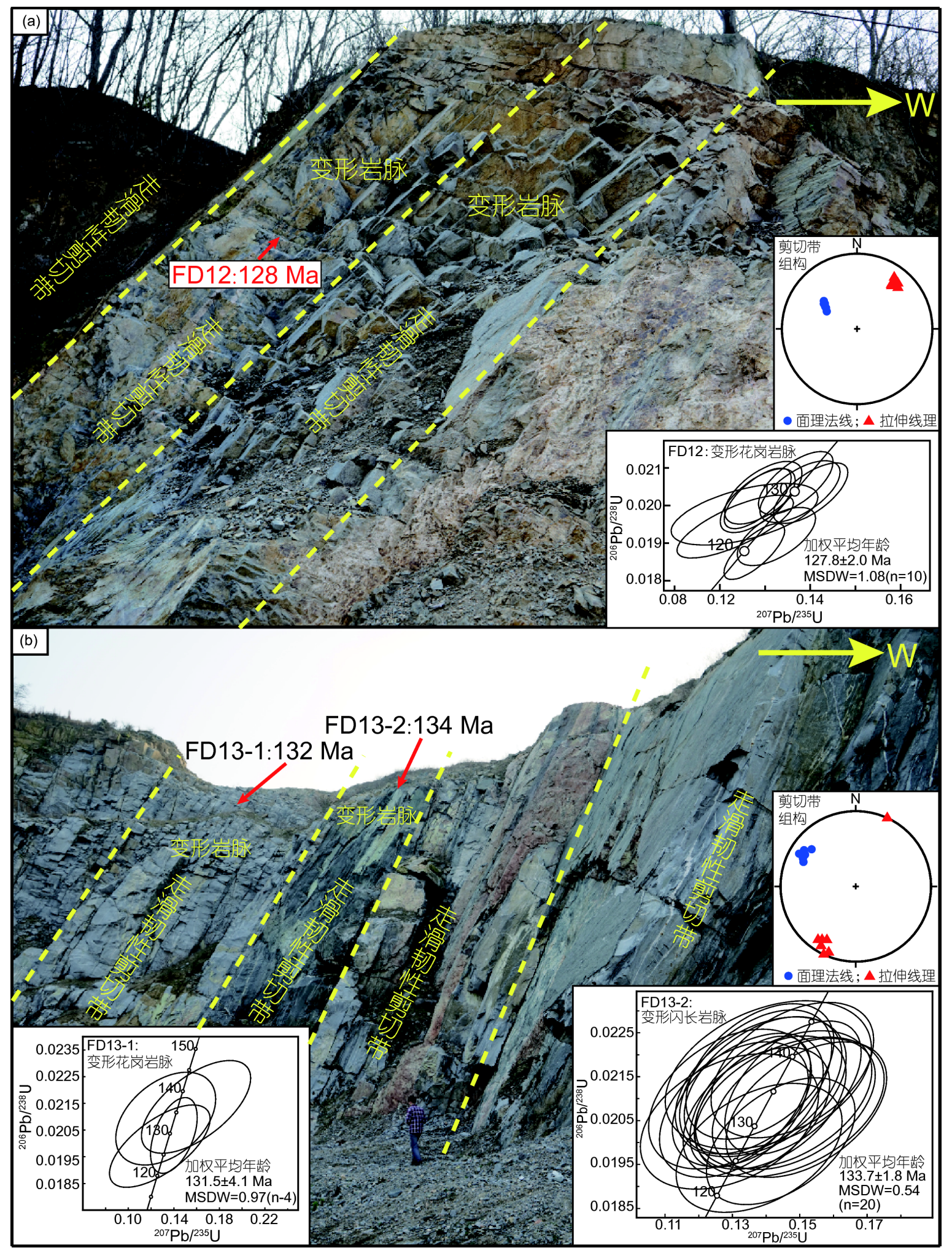

图 8 矨庐断裂带张八岭隆起南段早白严世岩脉内发育的晚期走滑韧性剪切带、变形组构赤平投影及锆石U-Pb年龄谐和图 (a) 肥东解集梁巷东南; (b) 肥东解集大邵东南采场, 位置见图3 
压事件. 野外可见, 沂沭地堑内上白严统王氏组与下白 严统大盛群之间存在着角度不整合(Zhang等，2003). 这一系列事实表明, 郯庐断裂带早白严世末(或晚白严 世初)的左行平移活动是区域挤压的结果. 值得指出的 是, 在东北地区(李娟和舒良树, 2002)与东南沿海地区 (舒良树和周新民, 2002; Shu等, 2009), 均存在早白严 世末(或晚白严世初)挤压事件的记录，指示这是中国 东部大陆边缘普通经历的一期重要挤压事件.

\section{5 晚白严世期间伸展活动}

在晚白严世期间，郯庐断裂带转变为弱伸展活动 (图9)。与早白严世广泛而强烈岩浆活动形成鲜明对照 的是, 晚白严世沿断裂带没有发生岩浆活动. 在沂沭地 堑内, 弱伸展活动仅局部控制发育有上白严统沉积, 整 体上为隆起状态(Zhu等, 2012). 在郯庐断裂带山东段 北部，其弱伸展活动并没有直接控制胶莱盆地的发育. 该盆地西边界为北东向的景芝断裂，盆地内部主要是 近东西向断层活动性最强，所控制的沉降中心呈近东 西向展布(图9b). 在郯庐断裂带安徽段, 其弱伸展活动 而成为合肥盆地的东界，但盆地内部仍然是近东西向 断层活动性最强, 发育的沉降带呈东西向展布(图9c). 利用断层擦痕反演应力场显示(Zhu等，2012)，晚白严 世时期区域应力状态为近南北向拉张(图9a). 在此应 力作用下，北东走向的郯庐断裂带为斜向拉张，再加 之区域上弱的伸展应力，从而呈现为弱伸展活动. 也 正是这一应力状态，使得胶莱盆地与合肥盆地内近东 西走向的正断层活动最强(正向拉张), 从而使盆地转 变为东西向的沉降格局.

\section{4 断裂带演化对西太平洋俯冲历史的指示}

\section{1 矨庐断裂带与华北克拉通东部晚中生代演化 对比}

\subsection{1 晚侏罗世初平移与燕山运动 $\mathrm{A}$ 幕}

华北克拉通北部的燕山构造带以发生过燕山运动 而闻名. 燕山运动是指侏罗-白严纪期间区域挤压中发 生的构造运动，最早由翁文影先生提出(Wong，1926, 1927), 具体包括晚侏罗世髺䯽山组或兰旗组与下伏地 层之间角度不整合所指示的燕山运动 $\mathrm{A}$ 幕，以及土城 子组或后城组与上覆早白严世火山岩之间角度不整合
所指示的燕山运动 $\mathrm{B}$ 幕. 上、下白严统之间角度不整 合(Wong, 1929; 黄汲清, 1960)所代表的挤压事件可称 为燕山运动 $C$ 幕. 晚侏罗世火山活动期(即燕山运动 $A$ 幕与 $\mathrm{B}$ 幕之间) 也被称为燕山运动中间幕 (赵越等, 2004).

前人通过对燕山地区燕山运动 $\mathrm{A}$ 幕角度不整合 上、下层位内火山岩的锆石定年，限定这期变形应发 生在165Ma左右(中侏罗世晚期; 赵越等，2004; 刘健 等, 2006; 李海龙等, 2014). 由此可见, 㸚庐断裂带中 侏罗世末的左行平移与燕山运动 $\mathrm{A}$ 幕基本上同时发生, 两者皆为区域挤压的产物.

在燕山构造带上，燕山运动 $\mathrm{A}$ 幕挤压事件形成了 一系列北东至北东东走向的逆冲断层(Davis等，2001; 张长厚等, 2011; Wang Y等, 2011), 指示了区域WNWESE向挤压. 在华北克拉通中部, 自东向西呈现为北北 东走向的太行山冲断带、山西断褶带和吕梁山冲断 带, 其间发育了一系列纵向褶皱(如沈水向斜、宁静向 斜、大同向斜)，显然也是WNW-ESE向挤压变形的产 物(廖昌珍等，2007; 张岳桥等，2007; Liu S F等, 2013). 这些地区上侏罗统的普遍缺失及逆冲型㓞性剪 切带的 ${ }^{40} \mathrm{Ar}{ }^{39} \mathrm{Ar}$ 定年结果(Wang和Li, 2008)也指示这期 缩短变形发生中侏罗世末的燕山运动 $\mathrm{A}$ 幕(张岳桥等, 2007). 这些现象表明, 燕山运动 $A$ 幕缩短变形在华北克 拉通东部普遍存在，郯庐断裂带在中侏罗世末的左行 平移活动与这一变形事件相吻合. 由于这期变形事件 的挤压方向近垂直于炏庐断裂带走向，从而该先存、 陡立的断裂带仅局部活动.

华北克拉通在晚侏罗世燕山运动中间幕期间(介 于 $\mathrm{A}$ 幕与 $\mathrm{B}$ 幕之间), 处于广泛的隆起状态. 除了燕山构 造带出现了较大规模的火山喷发而形成火山岩盆地 外，华北克拉通东部其他地区广泛缺失晚侏罗世沉积 (张岳桥等, 2007; 陈印等, 2009). 这期间岩浆活动还出 现在辽东、胶北及皖北蚌埠地区(Wu等, 2005b; Li S G 等, 2014; 林少泽等, 2014; 宋利宏等, 2016). 前人通过 对晚侏罗世岩浆岩的研究 (Gao等，2004；Zhang等， 2008; Jiang等, 2010; Yang等, 2010, 2012), 认为华北 克拉通东部在此期间处于伸展环境. 近年来, 通过对医 巫闾山变质核杂岩(Zhang等，2012)、喀喇沈变质核杂 岩(林少泽等，2014)、玲珑伸展穹窿(Charles等，2011; 林少泽等, 2013)及克拉通北缘裂谷盆地(Qi等, 2015)的 构造研究, 也表明晚侏罗世发生过伸展活动. 总之, 在 


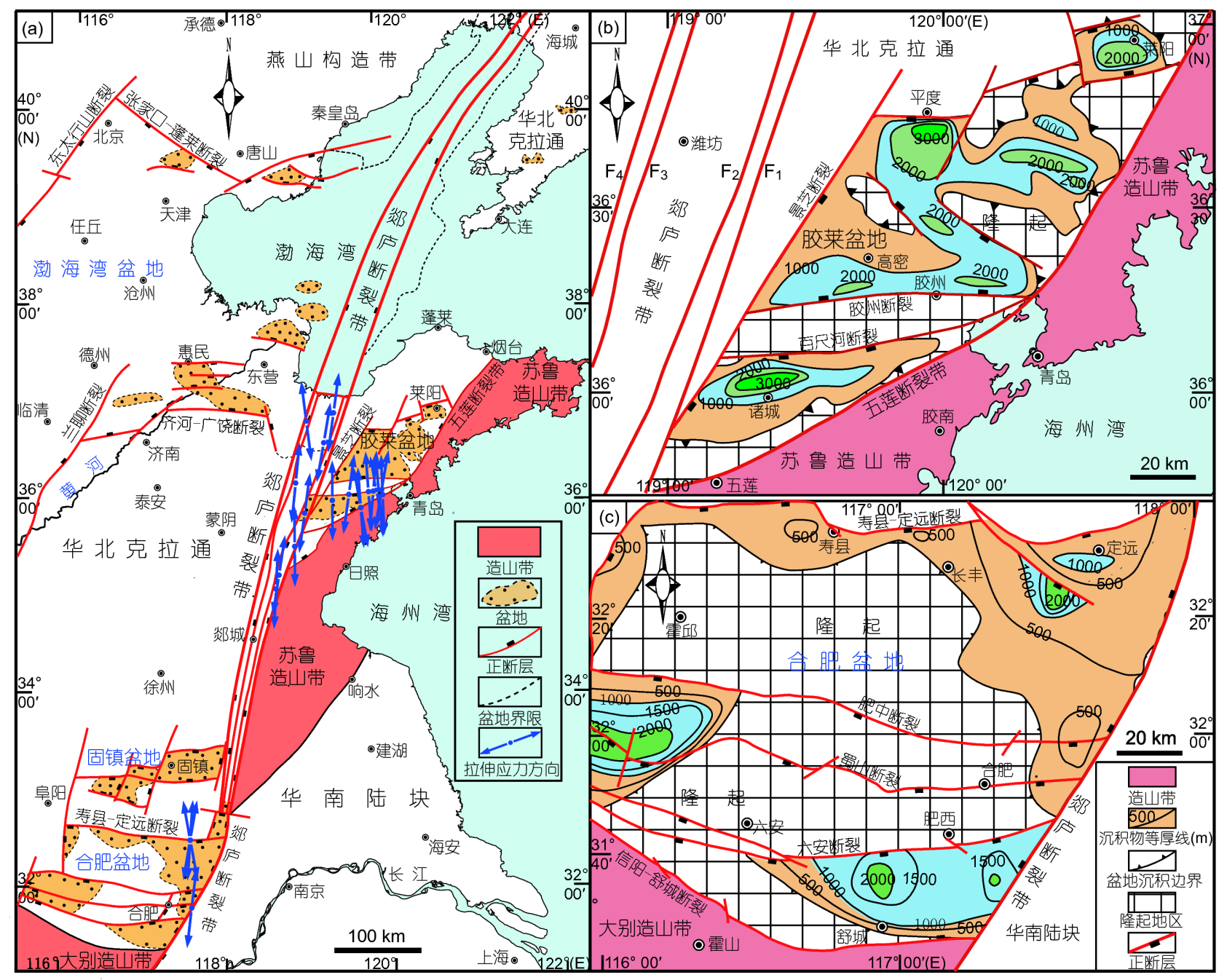

图 9 欵庐断裂带及其周边晚白严世伸展构造与盆地分布图

(a) 郯庐断裂带中段及周边晚白严世伸展构造简图; (b) 晚白严世胶莱盆地沉积格局图; (c) 晚白严世合肥盆地沉积格局图. 据Zhu等(2012)略改

晚侏罗世期间，华北克拉通东部总体处于弱伸展背景 下的区域性隆升，部分地区出现岩浆活动。在此背景 下, 郯庐断裂带处于构造活动的平静期.

\subsection{2 早白严世初平移与燕山运动 $B$ 幕}

燕山运动 $\mathrm{B}$ 幕造成的角度不整合上、下皆发育有 火山岩. 通过对这些火山岩的同位素定年, 指示该幕挤 压事件发生时间为139 138 Ma(早白严世初; 孙立新等, 2007; 陈印等, 2013; 以及其中参考文献). 显然, 燕山运 动 $\mathrm{B}$ 幕与矨庐断裂带早白严世初的左行平移活动基本 同时.

在燕山构造带上，燕山运动 $\mathrm{B}$ 幕造成了广泛的缩
短变形, 形成了一系列近东西向的褶皱和逆冲断层 (张 长厚等，2011)，显示为中生代以来最强的一期挤压事 件. 卷入这期变形的为前白严系, 在变质基底内还形成 了逆冲型韧性剪切带。早白严世初云蒙山岩基 (145 141Ma; Zhu等, 2015b)北缘发育的四合堂逆冲型 剪切带, 具有较高研究程度, 呈现为上盘向南南西的逆 冲，一系列年代学数据指示逆冲活动发生在 140 137Ma(Davis等, 1996; Passchier等, 2005; Wang T 等, 2011; Zhu等, 2015b), 显然属于燕山运动B幕产物. 这些构造现象表明，燕山运动 $\mathrm{B}$ 幕变形是区域上近南 北向挤压的结果．这一区域应力场，有利于北东至北 北东走向郯庐断裂带的左行平移活动，使得该断裂带 
在早白严世初的平移活动最为强烈.

\subsection{3 早白严世期间伸展活动与克拉通峰期破坏}

早白严世是华北克拉通破坏的峰期(朱日祥等, 2012). 这期间在克拉通东部呈现为广泛而强烈的伸展 活动, 出现了一系列变质核杂岩、伸展穹隆、伸展盆 地及面状分布的、中酸性为主的岩浆活动. 变质核杂 岩与伸展穹窡主要出现在克拉通北部的燕山构造带上 及辽南地区, 分别有房山岩浆穹窟、云蒙山核杂岩、 喀喇沁伸展穹穉、瓦子峪核杂岩及辽南-万福核杂 岩、玲珑伸展穹窡等(图4). 它们的形成时代为 135 129Ma(Lin等, 2008; Wang T等, 2011; Zhang等, 2012; Liu J L等, 2013; Zhu等, 2015b), 指示了 135Ma开 始的伸展活动. 这些早白严世变质核杂岩与伸展穹㶻 一致指示了WNW-ESE向的区域伸展方向，与矨庐断 裂带在早白严世早-中期伸展方向相吻合(图4), 反映 整个华北克拉通东部稳定的区域伸展应力状态. 华北 克拉通东部早白严世伸展盆地也是主要受控于北东向 正断层的活动, 与㸚庐断裂带具有类似的活动规律. 克 拉通东部早白严世期间广泛而强烈的岩浆活动，一方 面导致了这期间火山岩的广泛分布，另一方面也出现 了大量的侵入体, 并显示岩浆活动的峰期为 $125 \mathrm{Ma}$ (Wu等, 2005a; 朱日祥等, 2012).

总之, 华北克拉通东部显示早白严世峰期破坏特 征，表现为强烈而广泛的伸展与岩浆活动. 这一峰期 破坏的开始时间应为 136 135Ma，岩浆活动峰期为 $125 \mathrm{Ma}$, 持续至早白严世末. 㸚庐断裂带在早白严世期 间强烈的伸展活动就是出现在克拉通峰期破坏这一背 景下.

\subsection{4 早白严世末平移与克拉通峰期破坏结束}

在华北克拉通东部，上、下白严统之间存在着角 度不整合已被许多学者所认同(黄汲清, 1960; 朱大岗 等, 1999; 马寅生等, 2002; 邛志波等, 2003; 邓晋福等, 2004), 并被当作燕山运动最后一期挤压事件(C幕). 这 一挤压事件代表了重要的构造转折，标志着华北克拉 通东部峰期破坏的结束 $(\mathrm{Wu}$ 等， $2005 \mathrm{a}$; 朱日祥等, 2012). 华北克拉通东部广泛发育的早白严世伸展盆地 (图4), 皆因这一挤压事件而反转、抬升与消亡. 区内 广泛出现的早白严世岩浆活动也因这一挤压事件而结 束. 显然, 淡庐断裂带早白严世末的左行平移活动, 区
域挤压事件的反映.

\subsection{5 晚白严世区域弱伸展背景}

在晚白严世期间，整个华北克拉通东部皆处于岩 浆活动的平静期, 伸展盆地仅零星发育(图9a), 总体上 处区域性隆起状态. 通过对晚白严世胶莱盆地与合肥 盆地的构造研究(Zhu等，2012)，指示当时处于区域性 伸展背景. 但是, 各种构造现象表明, 华北克拉通东部 当时为弱伸展环境, 与早白严世强烈伸展环境形成鲜 明对比. 正是在此弱伸展背景下, 淡庐断裂带晚白严 世呈现为弱伸展活动, 两侧发育了胶莱与合肥盆地, 代表了华北克拉通东部当时相对较强的伸展活动带.

通过对比㸚庐断裂带与华北克拉通东部晚中生代 演化历史，揭示了炻庐断裂带晚中生代演化的区域背 景, 也显示了大型断裂带是区域动力学演化的重要记 录者. 通过对比并将两者信息互相补充，可以更完整 地指示整个华北克拉通东部晚中生代的动力学过程 (图10). 晚中生代时期, 华北克拉通东部的三期挤压事 件(燕山运动 $\mathrm{A} 、 \mathrm{~B} 、 \mathrm{C}$ 幕), 在郯庐断裂带上反映为三 期压扭性左行平移活动. 而挤压事件之间的区域性拉 张，导致该断裂带转变为正断层活动，从而控制伸展 盆地的发育. 详细恢复华北克拉通东部与郯庐断裂带 的演化历史，显示区域性挤压事件相对短暂，而区域 性伸展活动皆持续时间相对较长(图10). 在晚中生代 时期，华北克拉通经历了弱伸展(晚侏罗世) $\rightarrow$ 强伸展 (早白严世) $\rightarrow$ 弱伸展(晚白严世)演变, 其间的转换及开 始与结束皆发生了一期区域性挤压事件. 正是早白严 世强伸展期, 华北克拉通东部发生了岩石圈强烈减薄 与克拉通峰期破坏. 克拉通峰期破坏的开始与结束时 期, 均出现了一期挤压事件.

\section{2 对西太平洋俯冲历史的指示}

前文对比表明，䣊庐断裂带晚中生代的演化实际 上是华北克拉通东部同期演化的缩影. 通过进一步与 东北及华南东部晚中生代大地构造对比(Xu等，1987， 1993; Li，2000; Ren等, 2002; Meng, 2003; Wu等, 2005a; Zhu等，2010，2012; Wang T等，2011; Li等， 2012; Li J H等, 2014; 顾承串等, 2016), 可见整个中国 东部大陆边缘在晚中生代具有相似的构造演化历史, 而向西则转变为不同的地质特征. 如前文所述, 㸚庐断 裂带周边从早白严世早-中期、晚期至晚白严世，区域 


\begin{tabular}{|c|c|c|c|c|c|c|c|}
\hline \multicolumn{2}{|c|}{ 地质年代 } & 地 层 & $\begin{array}{l}\text { 淡庐断裂带 } \\
\text { 演化史 }\end{array}$ & $\begin{array}{l}\text { 华北克拉通 } \\
\text { 东部演化史 }\end{array}$ & $\begin{array}{l}\text { 燕山 } \\
\text { 运动 }\end{array}$ & 应力状态 & 动力学背景 \\
\hline \multirow{6}{*}{$\begin{array}{l}\text { 白 } \\
\text { 严 } \\
\text { 纪 }\end{array}$} & \multirow[t]{2}{*}{ 晚 } & 王氏组/张桥组 & 正断层活动 & \multirow[t]{2}{*}{$\begin{array}{l}\text { 区域隆起与 } \\
\text { 局部发育断陷盆地 }\end{array}$} & & $\begin{array}{l}\text { NS向 } \\
\text { 弱拉张 }\end{array}$ & 大洋板片高角度向N俯冲与海沟后退 \\
\hline & & & 左行平移 & & C幕 & NS向挤压 & 大洋板片低角度向N俯冲与海沟前进 \\
\hline & \multirow{4}{*}{ 早 } & 大盛群/响导铺组 & \multirow{3}{*}{$\begin{array}{c}\text { 强烈 } \\
\text { 正断层活动 }\end{array}$} & \multirow{3}{*}{$\begin{array}{l}\text { 广泛发育断陷盆地, } \\
\text { 出现变质核杂岩与 } \\
\text { 强烈岩浆活动 }\end{array}$} & \multirow{3}{*}{ 中间幕 } & $\begin{array}{c}\text { NNW-SSE向 } \\
\text { 拉张 } \\
\end{array}$ & \\
\hline & & 青山组/毛坦厂组 & & & & WNW-ESE向 & 伊泽奈崎板片高角度 \\
\hline & & $\begin{array}{c}\text { 莱阳群/蒙阴组 } \\
\text { / 朱巷组/凤凰、台组 }\end{array}$ & & & & 强拉张 & \\
\hline & & & 强左行平移 & & B幕 & NS向强挤压 & 伊泽奈崎板片低角度向NNW俯冲与海沟前进 \\
\hline \multirow{4}{*}{$\begin{array}{l}\text { 侏 } \\
\text { 罗 } \\
\text { 纪 }\end{array}$} & 晚 & & 平静期 & $\begin{array}{l}\text { 区域隆起与 } \\
\text { 局部岩浆活动 }\end{array}$ & & NS向弱拉张 & 伊泽奈崎板片高角度俯冲 \\
\hline & \multirow{2}{*}{ 中 } & & 局部左行平移 & NW-SE向缩短构造 & A幕 & NW-SE向挤压 & 伊泽奈崎板片低角度俯冲与海沟前进 \\
\hline & & 三台组/三尖铺组 & & & & & \\
\hline & 早 & 坊子组/防虎山组 & & & & & \\
\hline
\end{tabular}

图 10 矨庐断裂带晚中生代演化历史与区域背景汇总

拉张方向由WNW-ESE向、NW-SE向转变为近N-S(图 4、5和9), 显示了顺时针方向的转变(Zhu等, 2012). 而 同期古太平洋板块运动方向也呈现为类似的变化规律 (Engebretson等，1985; Maruyama等，1997; Cottrell和 Tarduno, 2003; Sager, 2006; Beaman等, 2007), 指示华 北克拉通东部这期间的伸展活动属于远场弧后拉张, 是古太平洋板块作用的结果(Zhu等，2012). 这些现象 表明, 华北克拉通东部晚中生代的动力学演化, 主要受 控于古太平洋板块的俯冲作用，所形成的构造属于滨 太平洋构造. 对华北克拉通东部晚中生代动力学演变 的深入认识，也可以进一步加深人们对西太平洋区板 块活动历史的认识. 继中三叠世起源之后，䣊庐断裂 带在中侏罗世末首次复活而局部发生了左行平移活 动. 这次平移活动与华北克拉通上燕山运动 $\mathrm{A}$ 幕同时 发生，所形成的构造走向平行于当时的西太平洋俯冲 带，指示为WNW-ESE向区域挤压的结果. 这期构造是 华北克拉通上首次出现平行于西太平洋俯冲带的构 造，叠加在早期近东西向古亚洲与古特提斯构造之上, 显然应是当时东部太平洋区伊泽奈崎板块向华北克拉 通下俯冲的结果, 属于活动陆缘缩短构造. 伊泽奈崎板 块的初始活动时间与方式目前并不明确(Engebretson 等, 1985; Maruyama等, 1997). 然而, 华北克拉通东部
中侏罗世末地质记录指示，伊泽奈崎板块向华北克拉 通下俯冲的开始时间应为中侏罗世末，应以低角度向 北西西方向俯冲(图11a). 由此可见，华北克拉通上的 燕山 $\mathrm{A}$ 幕构造及郯庐断裂带同期的左行平移活动，代 表了滨太平洋构造的开始. 值得指出的是，华北克拉 通东部并没有出现中侏罗世末岩浆弧现象，应处于岩 浆弧以西的弧后地区. 当时的朝鲜半岛及其东侧的日 本地区可能处于岩浆弧环境(Maruyama等，1997)。不 过，即使俯冲的伊泽奈崎板片脱水交代了上覆地幔楔， 但是侏罗纪时期华北克拉通依然处于很厚的状态，结 果古太平洋俯冲带在那个时期是冷的，这样板片脱水 不可能在这样的冷俯冲带引起弧岩浆作用(郑永飞等, 2016).

郯庐断裂带在晚侏罗世期间没有显示明显的活动 迹象. 华北克拉通东部同期呈现为弱伸展活动与局部 的岩浆活动，并以区域性隆升为特征. 这一活动陆缘 上的特征与弧后弱拉张背景相吻合. 推测当时伊泽奈 崎板块可能在早白严世时期俯冲角度变陡，导致海沟 开始后退(板片后撤)，从而出现了弧后地区的弱拉张 与区域性隆升(图11b).

在早白严世初，郯庐断裂带再次发生了左行平移， 并向北延伸进入东北地区，属于晚中生代最强的一期 


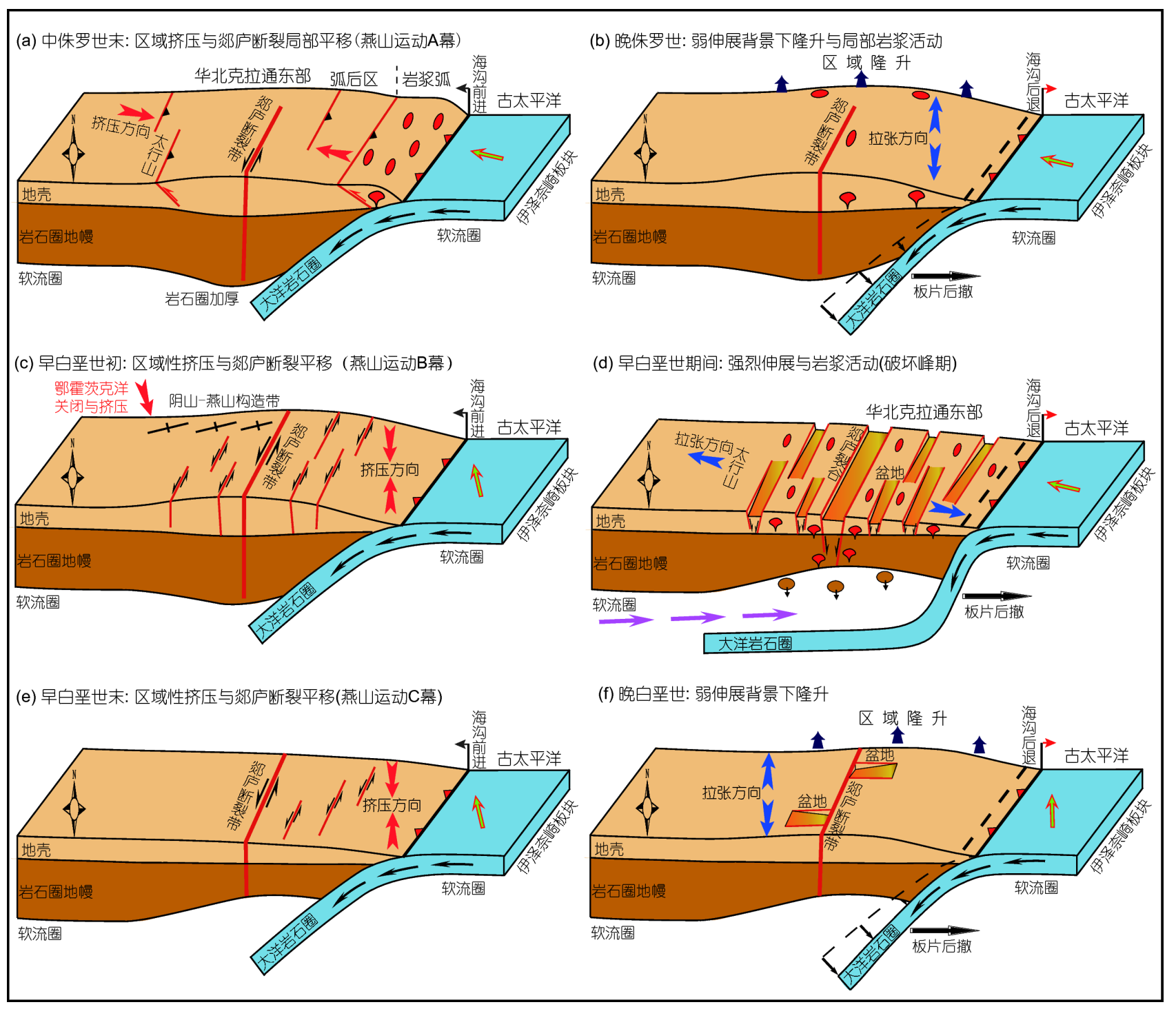

图 11 华北克拉通东部与欵庐断裂带晚中生代演化的动力学模式图

平移活动. 在华北克拉通上, 同期也出现了广泛的燕山 $\mathrm{B}$ 幕构造，指示了近南北向挤压作用. 伊泽奈崎板块早 白严世初向北北西高速、斜向、低角度俯冲(Engebretson等，1985; Maruyama等，1997)，应是中国东部这 时期挤压变形的主要动力来源 $(\mathrm{Xu}$ 等, 1987, 1993; Meng, 2003; Zhu等, 2005, 2010; Wang T等, 2011; Li J $\mathrm{H}$ 等, 2014; 顾承串等, 2016). 近年来的研究表明, 中亚 造山带内鄂霍茨克洋的最终关闭(斜向碰撞)发生在早 白严世初(Metelkin等, 2010; Pei等, 2011; Li等, 2012), 加剧了这时期的挤压作用(Zhu等, 2015b), 并与这期构 造活动强度向北加强现象相吻合(Meng, 2003; Wang T
等, 2011; Zhu等, 2015b). 正是在此周边板块的联合作 用下，出现了早白严世初郯庐断裂带的强烈左行平移 活动与周边的燕山 $\mathrm{B}$ 幕构造(图11c).

在早白严世期间，华北克拉通东部出现峰期破坏， 同期的郯庐断裂带发生强烈的伸展活动. 大量的研究 表明(Wu等，2005a；Zhu等，2010，2012；朱日祥等， 2012; Kusky等, 2014), 华北克拉通东部破坏与岩石圈 大规模减薄发生在弧后拉张的动力学背景下, 对应着 伊泽奈崎俯冲板片的后撤与海沟后退(图11d). 在早白 严世早-中期至晚期, 伊泽奈崎板块由向北西西运动转 变为向北西运动, 相应的海沟后退矢量方向由向南东 
东转变为向南东，从而导致华北克拉通东部伸展方向 由WNW-ESE向转变为NW-SE向(Zhu等, 2012).

在早白严世末，伊泽奈崎板块向北北西向运动可 能再次加速(Maruyama等, 1997), 由低角度俯冲替代 高角度俯冲，使得华北克拉通东部再次遭受区域性挤 压(燕山运动 $\mathrm{C}$ 幕), 郯庐断裂带再次发生了左行平移活 动(图11e), 从此结束了华北克拉通的峰期破坏.

进入晚白严世，古太平洋板块转变为向北低速运 动(Cottrell和Tarduno，2003；Sager，2006; Beaman等， 2007), 导致海沟后退与板片后撤. 在此期间, 由于海沟 后退矢量方向相应转变为向南(Zhu等，2012)，华北克 拉通东部出现近南北向拉张(图9a). 随着西太平洋海 沟的不断向东后退，中国东部更加远离海沟俯冲带， 从而晚白严世期间处于远场弱拉张背景. 在此动力学 背景下，郯庐断裂带呈现为弱伸展活动，华北克拉通 东部处于弱伸展背景下的区域性隆升(图11f).

\section{5 结论}

通过综合分析郯庐断裂带晚中生代演化的研究进 展, 并结合最新的研究成果, 可以得出主要结论如下:

(1) 中侏罗世末, 仅在大别造山带东缘段识别出郯 庐断裂带发生过左行平移活动，与燕山运动 $\mathrm{A}$ 幕同期, 皆为区域NW-SE向挤压的结果，代表了华北克拉通东 部受西太平洋俯冲作用的开始. 晚侏罗世期间，郯庐 断裂带处于构造与岩浆活动的平静期，而华北克拉通 东部处于弱伸展背景，可能指示了当时西太平洋海沟 初次后退.

（2）早白严世初, 㸚庐断裂带发生了强烈的左行平 移活动, 对应于燕山运动 $\mathrm{B}$ 幕, 为区域近南北向挤压的 结果. 伊泽奈崎板块向北北西向高速低角度俯冲是这 期大陆边缘区域性挤压的主要动力学背景. 当时北部 鄂霍茨克洋的最终关闭也加剧这期挤压作用.

(3) 在早白严世期间, 华北克拉通东部发生了峰期 破坏, 㸚庐断裂带也转变为强烈的伸展活动, 诱发了强 烈的岩浆活动, 控制了一系列伸展盆地的发育. 伊泽奈 崎俯冲板片后撤所造成的弧后拉张是这期强烈伸展活 动与克拉通峰期破坏的动力学背景.

（4）早白严世末, 㸚庐断裂带再次发生了左行平移 活动. 随后的晚白严世期间, 该断裂带转变为弱伸展活 动. 前者的挤压作用发生在古太平洋板块低角度快速 俯冲背景下, 而后者是俯冲大洋板片后撤的结果.

\section{参考文献}

邛志波, 刘文海, 黄志安, 张福生. 2003. 辽西上白严统大兴庄组地层 层序及时代. 地质通报, 22: 351-555

陈印, 朱光, 胡召齐, 张必龙, 向必伟. 2009. 华北克拉通东部盆地白 严-古近纪构造沉降的时空变化及其与克拉通破坏的关系. 地质 科学, 44: 836-854

陈印, 朱光, 姜大志, 张必龙. 2013. 四合堂剪切带活动时代及其对燕 山运动 $\mathrm{B}$ 幕时间的限定. 地质学报, 87: 295-310

邓晋福, 苏尚国, 赵国春, 刘翠. 2004. 华北燕山造山带构造要素组合. 高校地质学报, 10: 315-323

顾承串, 朱光, 翟明见, 林少泽, 宋利宏, 刘备. 2016. 依兰-伊通断裂带 中生代走滑构造特征与起源时代. 中国科学：地球科学, 46: 1579-1601

韩雨, 牛漫兰, 朱光, 吴齐, 李秀财, 王婷. 2015. 郯庐断裂带肥东段早 白严世中期走滑运动的年代学证据. 地球科学进展, 30: 922-939

黄汲清. 1960. 中国地质构造基本特征的初步总结. 地质学报, 40: 1237-1238

李海龙, 张宏仁, 渠洪杰, 蔡向民, 王猛. 2014. 燕山运动“绪动/A幕”的 本意及其锆石U-Pb年代学制约. 地质论评, 60: 1026-1042

李三忠，刘釒金，索艳慧，刘丽萍，钱存超，刘晓春，张国伟，赵国春. 2009. 华北克拉通东部地块和大别-苏鲁造山带印支期褶皱-逆冲 构造与动力学背景. 岩石学报, 25: 2031-2049

廖昌珍, 张岳桥, 温长顺. 2007. 鄂尔多斯盆地东缘边界带构造样式 及其区域构造意义. 地质学报, 81: 466-474

林少泽, 朱光, 严乐佳, 姜芹芹, 赵田. 2013. 胶东地区玲珑岩基隆升 机制探讨. 地质论评, 59: 832-844

林少泽, 朱光, 赵田, 宋利宏, 刘备. 2014. 燕山地区喀喇沁变质核杂 岩的构造特征与发育机制. 科学通报, 59: 3174-3189

李娟, 舒良树. 2002. 松辽盆地中、新生代构造特及其演化. 南京大 学学报: 自然科学, 38: 525-531

刘健, 赵越, 柳小明. 2006. 冀北承德盆地髺鬞山组火山岩的时代. 岩 石学报, 22: 2617-2630

刘伟, 徐春华, 宋明水, 李学田, 雷敏, 徐佑德, 邱连贵, 江来利, 杜森 官, 储东如. 2004. 试论合肥盆地燕山运动古城幕及其石油地质 意义. 安徽地质, 14: 1-5

马寅生, 吴满路, 曾庆利. 2002. 燕山及临区中新生代挤压与伸展的 转换和成矿作用. 地球学报, 23: 115-122

牛漫兰, 朱光, 刘国生, 王道轩, 宋传中. 2002. 㸚庐断裂带中南段中 生代岩浆活动的构造背景与深部过程. 地质科学, 37: 393-404

牛漫兰, 朱光, 刘国生, 宋传中, 王道轩. 2005. 郯庐断裂带中-南段新 生代火山活动与深部过程. 地质科学, 40: 390-403

石永红, 朱光, 王道轩. 2009. 郯庐断裂带张八岭隆起南段肥东群石 榴角闪岩变质 $P$ - $T$ 演化史对其构造属性的制约．岩石学报，25: 3319-3329

舒良树, 周新民. 2002. 中国东南部晚中生代构造作用. 地质论评, 48: 
249-260

宋利宏, 朱光, 赵田, 林少泽. 2016. 华北克拉通东南部蚌埠隆起晚中 生代花岗岩类岩体内变形记录与构造意义. 地质论评, 62: 400418

孙立新, 赵风清, 王惠初, 谷永昌, 冀世平. 2007. 燕山地区土城子组 划分、时代与盆地性质探讨. 地质学报. 81: 445-453

王浩乾, 朱光, 鞠林雪, 詹润, 林少泽, 严乐佳. 2012. 大别造山带南界 襄㚞-广济断裂带的演化规律与构造意义. 地质科学, 47: 290-305

王微, 宋传中, 李加好, 任升莲, 张妍, 刘欢, 杨帆. 2015. 䣊庐断裂带 肥东段剪切活动锆石U-Pb测年. 地质科学, 50: 800-809

王薇, 朱光, 张帅, 刘程, 顾承串. 2017. 合肥盆地中生代地层时代与 源区的碎屑锆石证据. 地质论评, 63: 956-977

詹润, 朱光, 杨贵丽, 林少泽, 严乐佳, 姜芹芹. 2013. 渤海海域新近纪 断层成因与动力学状况. 地学前缘, 20: 151-165

赵田, 朱光, 林少泽, 严乐佳, 姜芹芹. 2014. 郯庐断裂带张八岭隆起 段变质岩的原岩时代与变形机制. 中国科学：地球科学，44: 2112-2129

赵越, 张拴宏, 徐刚, 杨振宇, 胡健民. 2004. 燕山板内变形带侏罗纪 主要构造事件. 地质通报, 23: 854-863

张长厚, 李程明, 邓洪菱, 刘阳, 刘磊, 魏波, 李寒滨, 刘孜. 2011. 燕山太行山北段中生代收缩变形与华北克拉通破坏. 中国科学: 地球 科学, 41: 593-617

张岳桥, 董树文, 赵越, 张田. 2007. 华北侏罗纪大地构造: 综评与新 认识. 地质学报, 81: 1462-1480

张岳桥, 董树文. 2008. 䣊庐断裂带中生代构造演化史: 进展与新认 识. 地质通报, 27: 1371-1390

郑永飞, 陈仁旭, 徐峥, 张少兵. 2016. 俯冲带中的水迁移. 中国科学: 地球科学, 46: 253-286

朱大岗, 吴珍汗, 崔盛芹. 1999. 燕山地区中生代岩浆活动特征及其 与陆内造山作用关系. 地质论评, 45: 163-172

朱光, 宋传中, 牛漫兰, 刘国生, 王勇生. 2002. 䣊庐断裂带的岩石圈 结构及其成因分析. 高校地质学报, 8: 248-256

朱光, 王道轩, 刘国生, 牛漫兰, 宋传中. 2004. 郯庐断裂带的演化及 其对西太平洋板块运动的响应. 地质科学, 39: 36-49

朱日祥, 徐义刚, 朱光, 张宏福, 夏群科, 郑天愉. 2012. 华北克拉通破 坏. 中国科学: 地球科学, 42: 1135-1159

Beaman M, Sager W W, Acton G D, Lanci L, Pares J. 2007. Improved Late Cretaceous and Early Cenozoic paleomagnetic apparent polar wander path for the Pacific plate. Earth Planet Sci Lett, 262: 1-20

Charles N, Gumiaux C, Augier R, Chen Y, Zhu R X, Lin W. 2011. Metamorphic core complexes vs. synkinematic plutons in continental extension setting: Insights from key structures (Shandong Province, eastern China). J Asian Earth Sci, 40: 261-278

Chen L, Zheng T, Xu W. 2006. A thinned lithospheric image of the Tan-Lu Fault Zone, eastern China: Constructed from wave equation based receiver function migration. J Geophys Res, 111: B09312
Chung S L. 1999. Trace element and isotope characteristics of Cenozoic Basalts around the Tan-Lu Fault with implications for the Eastern Plate Boundary between north and south China. J Geol, 107: 301312

Cottrell R D, Tarduno J A. 2003. A late Cretaceous pole for the Pacific plate: Implications for apparent and true polar wander and the drift of hotspots. Tectonophysics, 362: 321-333

Davis G A, Qian X, Zheng Y, Tong H, Yu H, Gehrels G E, Shafiqullah M, Fryxell J. 1996. Mesozoic deformation and plutonism in the Yunmeng Shan: A metamorphic core complex north of Beijing, China. In: The Tectonic Evolution of Asia. New York: Cambridge University Press. 253-280

Davis G A, Zheng Y D, Wang C, Darby B J, Zhang C, Gehrels G E. 2001. Mesozoic tectonics on Hebei and Liaoning Provinces, Northern China. GSA Memoir, 194: 171-197

Engebretson D C, Cox A, Gorden R G. 1985. Relative motions between oceanic and continental plates in the Pacific basin. Geol Soc Am Spec Paper, 206: 1-59

Gao S, Rudnick R L, Yuan H L, Liu X M, Liu Y S, Xu W L, Ling W L, Ayers J, Wang X C, Wang Q H. 2004. Recycling lower continental crust in the North China Craton. Nature, 432: 892-897

Gilder S A, Leloup P H, Courtillot V, Chen Y, Coe R S, Zhao X, Xiao W, Halim N, Cogné J P, Zhu R. 1999. Tectonic evolution of the Tancheng-Lujiang (Tan-Lu) fault via Middle Triassic to Early Cenozoic paleomagnetic data. J Geophys Res, 104: 15365-15390

Gu C C, Zhu G, Zhang S, Liu C, Li Y J, Lin S Z, Wang W. 2017. Cenozoic evolution of the Yilan-Yitong Graben in NE China: An example of Graben formation controlled by pre-existing structures. J Asian Earth Sci, 146: 168-184

Jiang Y H, Jiang S Y, Ling H F, Ni P. 2010. Petrogenesis and tectonic implications of Late Jurassic shoshonitic lamprophyre dikes from the Liaodong Peninsula, NE China. Mineral Petrol, 100: 127-151

Kusky T M, Windley B F, Wang L, Wang Z S, Li X Y, Zhu P M. 2014. Flat slab subduction, trench suction, and craton destruction: Comparison of the north China, Wyoming, and Brazilian cratons. Tectonophysics, 630: 208-221

Li J H, Zhang Y Q, Dong S W, Johnston S T. 2014. Cretaceous tectonic evolution of South China: A preliminary synthesis. Earth-Sci Rev, 134: $98-136$

Li S G, Wang S J, Guo S S, Xiao Y L, Liu Y C, Liu S A, He Y S, Liu J L. 2014. Geochronology and geochemistry of leucogranites from the southeast margin of the North China Block: Origin and migration. Gondwana Res, 26: 1111-1128

Li S Q, Chen F K, Siebel W, Wu J D, Zhu X Y, Shan X L, Sun X M. 2012. Late Mesozoic tectonic evolution of the Songliao basin, NE China: Evidence from detrital zircon ages and Sr-Nd isotopes. 
Gondwana Res, 22: 943-955

Li S Z, Jahn B M, Zhao S J, Dai L M, Li X Y, Suo Y H, Guo L L, Wang Y M, Liu X C, Lan H Y, Zhou Z Z, Zheng Q L, Wang P C. 2017. Triassic southeastward subduction of North China Block to South China Block: Insights from new geological, geophysical and geochemical data. Earth-Sci Rev, 166: 270-285

Li X H. 2000. Cretaceous magmatism and lithospheric extension in Southeast China. J Asian Earth Sci, 18: 293-305

Li Z X. 1994. Collision between the North and South China blocks: A crustal-detachment model for suturing in the region east of the Tanlu fault. Geology, 22: 739-742

Lin S F, Li Z X. 1995. Collision between the North and South China blocks: A crustal-detachment model for suturing in the region east of the Tanlu fault: Comment and reply. Geology, 23: 574-575

Lin W, Faure M, Monie P, Scharer U, Panis D. 2008. Mesozoic extensional tectonics in Eastern Asia: The South Liaodong Peninsula metamorphic core complex (NE China). J Geol, 116: $134-154$

Liu B, Zhu G, Zhai M J, Gu C C, Liu S. 2015. Quaternary faulting of the Jiangsu part of the Tan-Lu Fault Zone, East China: Evidence from field investigations and OSL dating. J Asian Earth Sci, 114: 89-102

Liu J L, Shen L, Ji M, Guan H, Zhang Z, Zhao Z. 2013. The Liaonan/ Wanfu metamorphic core complexes in the Liaodong Peninsula: Two stages of exhumation and constraints on the destruction of the North China Craton. Tectonics, 32: 1121-1141

Liu S F, Su S, Zhang G W. 2013. Early Mesozoic basin development in North China: Indications of Cratonic deformation. J Asian Earth Sci, 62: $221-236$

Maruyama S, Isozaki Y, Kimura G, Terabayashi M. 1997. Paleogeographic maps of the Japanese Islands: Plate tectonic synthesis from $750 \mathrm{Ma}$ to the present. Isl Arc, 6: 121-142

Meng Q R. 2003. What drove late Mesozoic extension of the northern China-Mongolia tract? Tectonophysics, 369: 155-174

Mercier J L, Hou M J, Vergély P, Wang Y M. 2007. Structural and stratigraphical constraints on the kinematics history of the Southern Tan-Lu Fault Zone during the Mesozoic Anhui Province, China. Tectonophysics, 439: 33-66

Metelkin D V, Vernikovsky V A, Kazansky A Y, Wingate M T D. 2010

Late Mesozoic tectonics of Central Asia based on paleomagnetic evidence. Gondwana Res, 18: 400-419

Okay A I, Şengör A M C. 1992. Evidence for intracontinental thrustrelated exhumation of the ultra-high-pressure rocks in China. Geology, 20: 411-414

Passchier C W, Zhang J S, Konopasek J. 2005. Geometric aspects of synkinematic granite intrusion into a ductile shear zone-An example from the Yunmengshan core complex, northern China. Geol Soc Lond Spec Publ, 245: 65-80

Pei J L, Sun Z M, Liu J, Liu J, Wang X S, Yang Z Y, Zhao Y, Li H B. 2011. A paleomagnetic study from the Late Jurassic volcanics (155 Ma), North China: Implications for the width of Mongol-Okhotsk Ocean. Tectonophysics, 510: 370-380

Qi G W, Zhang J J, Wang M. 2015. Mesozoic tectonic setting of rift basins in eastern North China and implications for destruction of the North China Craton. J Asian Earth Sci, 111: 414-427

Ren J Y, Tamaki K, Li S T, Zhang J X. 2002. Late Mesozoic and Cenozoic rifting and its dynamic setting in Eastern China and adjacent areas. Tectonophysics, 344: 175-205

Sager W W. 2006. Cretaceous paleomagnetic apparent polar wander path for the Pacific plate calculated from Deep Sea Drilling Project and Ocean Drilling Program basalt cores. Phys Earth Planet Inter, 156: 329-349

Shu L S, Zhou X M, Deng P, Wang B, Jiang S Y, Yu J H, Zhao X X. 2009. Mesozoic tectonic evolution of the Southeast China Block: New insights from basin analysis. J Asian Earth Sci, 34: 376-391

Wang T, Zheng Y, Zhang J, Zeng L, Donskaya T, Guo L, Li J. 2011. Pattern and kinematic polarity of late Mesozoic extension in continental NE Asia: Perspectives from metamorphic core complexes. Tectonics, 30: TC6007

Wang Y. 2006. The onset of the Tan-Lu fault movement in eastern China: Constraints from zircon (SHRIMP) and ${ }^{40} \mathrm{Ar} /{ }^{39} \mathrm{Ar}$ dating. Terra Nova, 18: 423-431

Wang Y, Li H M. 2008. Initial formation and Mesozoic tectonic exhumation of an intracontinental tectonic belt of the northern part of the Taihang Mountain Belt, Eastern Asia. J Geol, 116: 155-172

Wang Y, Zhou L Y, Li J Y. 2011. Intracontinental superimposed tectonics-A case study in the Western Hills of Beijing, Eastern China. Geol Soc Am Bull, 123: 1033-1055

Wang Y S, Xiang B W, Zhu G, Jiang D Z. 2011. Structural and geochronological evidence for Early Cretaceous orogen-parallel extension of the ductile lithosphere in the northern Dabie orogenic belt, East China. J Struct Geol, 33: 362-380

Wong W H. 1926. Crustal Movement in eastern China. In: Proceedings of the Third Peri-Pacific Symposium. 462-485

Wong W H. 1927. Crustal movements and igneous activities in Eastern China since Mesozoic Time. Bull Geol Soc China, 6: 9-37

Wong W H. 1929. The mesozoic orogenic movement in Eastern China. Bull Geol Soc China, 8: 33-44

Wu F Y, Lin J Q, Wilde S A, Zhang X, Yang J H. 2005a. Nature and significance of the Early Cretaceous giant igneous event in eastern China. Earth Planet Sci Lett, 233: 103-119

Wu F Y, Yang J H, Wilde S A, Zhang X O. 2005b. Geochronology, 
petrogenesis and tectonic implications of Jurassic granites in the Liaodong Peninsula, NE China. Chem Geol, 221: 127-156

Xu J W, Zhu G, Tong W X, Cui K R, Liu Q. 1987. Formation and evolution of the Tancheng-Lujiang wrench fault system: A major shear system to the northwest of the Pacific Ocean. Tectonophysics, 134: $273-310$

Xu J W, Ma G F, Tong W X, Zhu G, Lin S F. 1993. The TanchengLujiang Wrench Fault System. Hoboken: John Wiley \& Sons. 51-74

Xu J W, Zhu G. 1994. Tectonic models of the Tan-Lu Fault Zone, eastern China. Int Geol Rev, 36: 771-784

Yang D B, Xu W L, Wang Q H, Pei F P. 2010. Chronology and geochemistry of Mesozoic granitoids in the Bengbu area, central China: Constraints on the tectonic evolution of the eastern North China Craton. Lithos, 114: 200-216

Yang D B, Xu W L, Pei F P, Yang C H, Wang Q H. 2012. Spatial extent of the influence of the deeply subducted South China Block on the southeastern North China Block: Constraints from $\mathrm{Sr}-\mathrm{Nd}-\mathrm{Pb}$ isotopes in Mesozoic mafic igneous rocks. Lithos, 136-139: 246260

Yin A, Nie S Y. 1993. An indentation model for the North and South China collision and the development of the Tan-Lu and Honam Fault Systems, eastern Asia. Tectonics, 12: 801-813

Zhang B, Zhu G, Jiang D Z, Li C C, Chen Y. 2012. Evolution of the Yiwulushan metamorphic core complex from distributed to localized deformation and its tectonic implications. Tectonics, 31: TC4018

Zhang Q, Teyssier C, Dunlap J, Zhu G. 2007. Oblique collision between North and South China recorded in Zhangbaling and Fucha Shan (Dabie-Sulu transfer zone). Exhumation Associated with Continental Strike-Slip Fault System. Geol Soc Am Spe Paper, 434: 167-206

Zhang X H, Mao Q, Zhang H F, Wilde S A. 2008. A Jurassic peraluminous leucogranite from Yiwulüshan, western Liaoning,
North China craton: Age, origin and tectonic significance. Geol Mag, 145: 315-320

Zhang Y Q, Dong S W, Shi W. 2003. Cretaceous deformation history of the middle Tan-Lu fault zone in Shandong Province, eastern China. Tectonophysics, 363: 243-258

Zhao T, Zhu G, Lin S Z, Wang H Q. 2016. Indentation-induced tearing of a subducting continent: Evidence from the Tan-Lu Fault Zone, East China. Earth-Sci Rev, 152: 14-36

Zhu G, Wang Y S, Liu G S, Niu M L, Xie C L, Li C C. 2005. ${ }^{40} \mathrm{Ar} /{ }^{39} \mathrm{Ar}$ dating of strike-slip motion on the Tan-Lu fault zone, East China. J Struct Geol, 27: 1379-1398

Zhu G, Liu G S, Niu M L, Xie C L, Wang Y S, Xiang B W. 2009. Syncollisional transform faulting of the Tan-Lu fault zone, East China. Int J Earth Sci-Geol Rundsch), 98: 135-155

Zhu G, Niu M L, Xie C L, Wang Y S. 2010. Sinistral to normal faulting along the Tan-Lu Fault Zone: Evidence for geodynamic switching of the East China continental margin. J Geol, 118: 277-293

Zhu G, Jiang D Z, Zhang B L, Chen Y. 2012. Destruction of the eastern North China Craton in a backarc setting: Evidence from crustal deformation kinematics. Gondwana Res, 22: 86-103

Zhu G, Hu W, Song L H, Liu B. 2015a. Quaternary activity along the Tan-Lu fault zone in the Bohai Bay, East China: Evidence from seismic profiles. J Asian Earth Sci, 114: 5-17

Zhu G, Chen Y, Jiang D Z, Lin S Z. 2015b. Rapid change from compression to extension in the North China Craton during the Early Cretaceous: Evidence from the Yunmengshan metamorphic core complex. Tectonophysics, 656: 91-110

Zhu G, Wang Y S, Wang W, Zhang S, Liu C, Gu C C, Li Y J. 2017. An accreted micro-continent in the north of the Dabie Orogen, East China: Evidence from detrital zircon dating. Tectonophysics, 698: 47-64 